\title{
Analysis of genetic traits for drought tolerance in maize
}

\author{
R.W. Muhammad' ${ }^{2}$ A. Qayyum ${ }^{1}$, A. Hamza', M.Q. Ahmad', N.S. Naseer', \\ S. Liaqat ${ }^{1}$, B. Ahmad ${ }^{3}$, W. Malik ${ }^{1}$ and E. Noor ${ }^{1}$ \\ 1Department of Plant Breeding and Genetics, \\ Faculty of Agricultural Sciences and Technology, Bahauddin Zakariya University, \\ Multan, Pakistan \\ 2PARC Research and Training Station, Pakistan Agriculture Research Council, \\ Multan, Pakistan \\ ${ }^{3}$ Arid Zone Research Institute, PARC, Bahawalpur, Pakistan \\ Corresponding author: R.W. Muhammad \\ E-mail: waliparc@gmail.com \\ Genet. Mol. Res. 14 (4): 13545-13565 (2015) \\ Received March 11, 2015 \\ Accepted July 14, 2015 \\ Published October 28, 2015 \\ DOI http://dx.doi.org/10.4238/2015.October.28.15
}

ABSTRACT. Fifty-four genotypes of maize were crossed and evaluated in the field during the crop season in February 2012 under both normal and water stress conditions. To identify the major parameters responsible for variation among genotypes, single linkage cluster analysis and principle component analysis (PCA) were carried out. Thirteen characters were studied. The PCA showed that the first six components, with eigen values $>1$, contributed $82.30 \%$ of the variability among the genotypes under normal field irrigation conditions while other PCs (7-13) had eigen values less than 1. Under drought conditions, the first four PCs, with eigen values $>1$, contributed $64.79 \%$ of the variability among genotypes while the other PCs (5-13) had eigen values less than 1. In the absence of water stress, heritability ranged from $68 \%$ (sucrose content) to $99 \%$ (plant height) and genetic advance ranged between $158.43 \%$ for stomatal frequency and 0.87 for biological yield. Under drought conditions, the coefficient of variability (CV) was 1.43-7.79, whereas estimates of heritability ranged between 
$68 \%$ and $99 \%$ for sucrose content and leaf area, respectively. The values of genetic advance ranged between 153.41 for stomatal frequency and 0.47 for nitrogen content. CV was 1.52-7.38 under drought conditions. The results indicated that the plant characters studied were under the control of additive genetic effects and suggested that selection should lead to fast genetic improvements. Clusters with superior agronomic types were identified and could be exploited for the transfer of desirable genes to improve the yield potential of the maize crop.

Key words: Genotypic correlations; Principal component analysis; Heritability; General and specific combining ability; Zea mays L.

\section{INTRODUCTION}

Maize (Zea mays L.) is the world's most extensively grown cereal and is an important staple food in many developing countries (Morris et al., 1999). Worldwide, 159.53 million hectares are used to grow maize with a grain production of 817.11 million metric tons and overall yield of 5120 $\mathrm{kg}$ per hectare during 2009-10 (Anonymous, 2009-2010). In Pakistan, maize is sown on $1085.0 \mathrm{x}$ $10^{3}$ hectares with an annual production of $4631.0 \times 10^{3}$ tones and an average yield of $4268 \mathrm{~kg}$ per hectare. This yield is 1.25 times lower than that of the world grain yield per unit area (Anonymous, 2012-2013). Improvement in yield might be achieved through selection for germplasm attributes contributing to yield.

Characterization of heritability and genetic advance should enable breeders to identify superior parents and to initiate an efficient and productive crossing program. Correlation analysis provides information on the interrelationship of important plant attributes and, hence, is of value for developing a directional model for direct and/or indirect improvements in grain yield (Khan et al., 2004). Another approach, principal component analysis (PCA), has the benefit over cluster analysis that each statistic can be allotted to a single group (Khodadadi et al., 2011). Determination of combining ability and genetic variance components are important in breeding programs for hybridization (Fehr, 1993). In any breeding program, the choice of the optimal parents is the key to success. One of the most important principles in breeding programs for identifying hybrids with high yield is knowledge of the parent genetic structure and an understanding of combining ability (Ceyhan, 2003). Genetic information can be obtained through various quantitative genetic methods. One of the more favored approaches is line $\mathrm{x}$ tester analysis, which gives a better and more efficient method (Singh and Chaudhary, 1985). The line $x$ tester analysis method was suggested by Kempthorne (1957) and can be used to breed both self- and cross-pollinated plants, as well as determining desirable parents, crosses, and their general and specific combining ability effects.

Selection of the tester is crucial to the ultimate success of a hybrid development program. Testers can be related or unrelated to the lines being evaluated; they may have a high or low frequencies of favorable alleles. Testers that are either high or low yielding maize inbred lines have been developed for segregation base populations through self-pollination, or through visual selection among and within ear-to row progenies and testing for performance in hybrid combination (Hallauer and Miranda, 1990). Various studies have shown that non-additive genetic effects have an effective role in the inheritance of grain yield (Kara, 2001; Ashish and Singh, 2002; Motawei, 2006; Aly and Hassan, 2011). Maize grain yield combining ability has also been studied intensively 
and the findings have been extensively used in maize breeding programs (Kauffman et al., 1982; Fan et al., 2002; Barata and Carena, 2006). However, less research has been conducted on the combining ability of maize yield components or on the relationship between combining ability of grain yield and that of yield components (Fan et al., 2008; Mousa and Aly, 2011). The main objective of the present study was to estimate the variability, heritability, and linkage for yield and its related traits in maize. We also sought to determine the general combining ability of lines and testers and specific combining abilities of crosses for grain yield and yield components traits. This information will enable us to identify superior crosses for improving the yield in a breeding program for growth of maize under drought stress conditions.

\section{MATERIAL AND METHODS}

Ten inbred lines of maize (Table 1) were obtained in 2011 from the Institute of Agricultural Biotechnology \& Genetic Resources, National Agricultural Research Centre, Islamabad, Pakistan, and were crossed to four testers (Table 2) obtained from the Maize and Millet Research Institute, Sahiwal, Pakistan. Their new genetic combinations ( $F_{1}$ hybrids in Table 3$)$, along with their parents, were grown in 2012 and evaluated under two different conditions, either normal irrigation or drought stress conditions (50\% of normal normal irrigation). The experimental field was located at the Department of Plant Breeding and Genetics, Faculty of Agricultural Sciences and Technology, Bahauddin Zakaryia University, Multan, Pakistan, and situated at latitude $30.20^{\circ}$, longitude $71.48^{\circ}$, and altitude $124.97 \mathrm{~m}$. Field temperature ranged from 7.5 to $37.6^{\circ} \mathrm{C}$, relative humidity from 72.5 to $78.9 \%$, and rainfall ranged between 7 and $12 \mathrm{~mm}$ during the autumn season 2012. Each experimental unit was grown using a randomized complete block design with three replicates; the plot was $5 \mathrm{~m}$ long and rows were $80 \mathrm{~cm}$ apart. Seeds were planted in hills at a spacing of $25 \mathrm{~cm}$ along the row at the rate of three kernels per hill. Seedlings were thinned to one plant per hill at 21 days after planting. All agronomic field practices were applied as recommended.

Table 1. Names of the 10 lines used in this study and their parentage and origin.

\begin{tabular}{lccll}
\hline Variety No. & Line No. & Accession No. & Parentage & Origin \\
\hline V1 & L1 & 014955 & 000608(04) & Pakistan \\
V2 & L2 & 015084 & 000995(02) & Pakistan \\
V3 & L3 & 015114 & 001025(01) & Pakistan \\
V4 & L4 & 015135 & 001280(05) & Pakistan \\
V5 & L5 & 015224 & 003834(02) & Pakistan \\
V6 & L6 & 015167 & 002275(03) & Pakistan \\
V7 & L7 & 015030 & LINFINGHAUNG & China \\
V8 & L8 & TL 78A-37 & Mexico \\
V9 & L9 & 015125 & TL 76B 210 & Mexico \\
V10 & L10 & 015129 & P-3282 & Japan \\
\hline
\end{tabular}

Table 2. Names of the 4 testers used in this study and their origin.
\begin{tabular}{lcll}
\hline Variety No. & Line No. & Tester Name. & Origin \\
\hline V11 & T1 & Sahiwal 2002 & Pakistan \\
V12 & T2 & Agaiti 2002 & Pakistan \\
V13 & T3 & Ev-5098 & Pakistan \\
V14 & T4 & Ev-6098 & Pakistan \\
\hline
\end{tabular}




\begin{tabular}{|c|c|c|c|c|c|}
\hline Variety No. & Crosses & Names of germplasm & Variety No. & Crosses & Names of germplasm \\
\hline V15 & L1 1 T1 & 014955 x Sahiwal 2002 & V35 & L $6 \times 1$ & $015167 \times$ Sahiwal 2002 \\
\hline V16 & L1 $\times$ T2 & 014955 x Agaiti 2002 & V36 & L6 $\times$ T2 & 015167 x Agaiti 2002 \\
\hline V17 & L1 $1 \times$ T3 & 014955 x Ev-5098 & V37 & L6 $\times$ T3 & 015167 x Ev-5098 \\
\hline V18 & L1 1 T4 & 014955 x Ev-6098 & V38 & L6 $\times$ T4 & 015167 x Ev-6098 \\
\hline V19 & L2 $\times$ T1 & 015084 x Sahiwal 2002 & V39 & $\mathrm{L} 7 \times \mathrm{T} 1$ & $015030 \times$ Sahiwal 2002 \\
\hline V20 & L2 $\times$ T2 & 015084 x Agaiti 2002 & V40 & L7 $\times$ T2 & 015030 x Agaiti 2002 \\
\hline V21 & L2 $\times$ T3 & 015084 x Ev-5098 & V41 & L7 $\times$ T3 & 015030 x Ev-5098 \\
\hline V22 & $\mathrm{L} 2 \times \mathrm{T} 4$ & 015084 x Ev-6098 & V42 & $\mathrm{L} 7 \times \mathrm{T} 4$ & $015030 \times$ Ev-6098 \\
\hline V23 & L3 $\times$ T1 & 015114 x Sahiwal 2002 & V43 & L8 $\times$ T1 & $015125 \times$ Sahiwal 2002 \\
\hline V24 & L3 $\times$ T2 & 015114 x Agaiti 2002 & V44 & L8 $\times$ T2 & 015125 x Agaiti 2002 \\
\hline V25 & L3 $\times$ T3 & 015114 x Ev-5098 & V45 & L8 $\times$ T3 & $015125 \times$ Ev-5098 \\
\hline V26 & $\mathrm{L} 3 \times \mathrm{T} 4$ & 015114 x Ev-6098 & V46 & L8 $\times$ T4 & 015125 x Ev-6098 \\
\hline V27 & L4 $\times$ T1 & 015135 x Sahiwal 2002 & V47 & L9 $\times$ T1 & $015129 \times$ Sahiwal 2002 \\
\hline V28 & $\mathrm{L} 4 \times \mathrm{T} 2$ & 015135 x Agaiti 2002 & V48 & L9 $\times$ T2 & $015129 \times$ Agaiti 2002 \\
\hline V29 & L4 $\times$ T3 & 015135 x Ev-5098 & V49 & L9 $\times$ T3 & 015129 x Ev-5098 \\
\hline V30 & L4 $\times$ T4 & 015135 x Ev-6098 & V50 & $\mathrm{L} 9 \times \mathrm{T} 4$ & $015129 \times$ Ev-6098 \\
\hline V31 & L5 x T1 & $015224 \times$ Sahiwal 2002 & V51 & $\mathrm{L} 10 \times \mathrm{T} 1$ & $015262 \times$ Sahiwal 2002 \\
\hline V32 & L5 $\times$ T2 & 015224 x Agaiti 2002 & V52 & $\mathrm{L} 10 \times \mathrm{T} 2$ & 015262 x Agaiti 2002 \\
\hline V33 & L5 $\times$ T3 & 015224 x Ev-5098 & V53 & L10 x T3 & 015262 x Ev-5098 \\
\hline V34 & L5 $\times$ T4 & 015224 x Ev-6098 & V54 & L10 x T4 & $015262 \times$ Ev-6098 \\
\hline
\end{tabular}

Thirteen different morphological, physiological, and biochemical parameters (Table 4) were recorded from ten ear-marked plants in each plot during the cropping season. Analyses of variance (ANOVAs) were used to compare the characteristics. Heritability estimates were calculated using procedures given by Allard (1960). Phenotypic correlation coefficients among the traits were calculated. The average data were analyzed by numerical taxonomic techniques using the procedure of cluster and PCA described by Singh and Chaudhary (1985). The data were standardized and transformed for SLCA and PCA using the computer program MINITAB 13.2. Using character variations, the SLCA summarized the positioned genotypes in a dendrogram. Combining ability analysis was estimated using the line $x$ tester procedure suggested by Kempthorne (1957). Combined analysis of the two conditions (normal and water stress) was performed after testing the data for homogeneity.

\begin{tabular}{lll}
\multicolumn{2}{c}{ Table 4. List of characters used in this study and their abbreviations. } \\
\hline Serial No. & Abbreviation & Character name \\
\hline 1 & PH & Plant height \\
2 & LA & Leaf area \\
3 & NKE & Number of kernels per ear \\
4 & TGW & 1000-grain weight \\
5 & BY & Biological yield \\
6 & GYP & Grain yield per plant \\
7 & HI & Harvest index \\
8 & SF & Stomatal frequency \\
9 & SS & Stomatal size \\
10 & NC & Nitrogen contents \\
11 & PC & Protein contents \\
12 & SC & Sucrose contents \\
13 & OC & Oil contents \\
\hline
\end{tabular}




\section{RESULTS}

\section{Heritability under normal irrigation field conditions}

The analysis of variance and the analyses of heritability and genetic advance for the 54 genotypes indicated significant differences for all the characters under study (Table 5).

\begin{tabular}{|c|c|c|c|c|c|c|c|}
\hline Character & $M S(R)$ & MS (V) & MS (E) & Mean \pm SE & $h^{2}$ & GA & CV (\%) \\
\hline $\mathrm{PH}$ & 32.6 & $4,486.4^{* *}$ & 45.5 & $160.17 \pm 0.003$ & 99 & 1.75 & 1.43 \\
\hline LA & 58.0 & $34,219^{\star \star}$ & 217.0 & $368.64 \pm 0.001$ & 98 & 2.48 & 2.02 \\
\hline NKE & 352.0 & $42,854^{\star \star}$ & 221.0 & $292.95 \pm 0.001$ & 88 & 0.99 & 3.81 \\
\hline TGW & 189.0 & $7,620^{* *}$ & 96.1 & $247.39 \pm 0.002$ & 80 & 2.15 & 4.21 \\
\hline BY & 93.0 & $59,580^{\star \star}$ & 250.0 & $250.14 \pm 0.001$ & 99 & 0.87 & 3.4 \\
\hline GYP & 10.5 & $1,380.4^{\star *}$ & 8.2 & $55.23 \pm 0.005$ & 93 & 2.57 & 2.81 \\
\hline $\mathrm{HI}$ & 2.87 & $440.25^{\star \star}$ & 2.31 & $25.88 \pm 0.009$ & 76 & 0.89 & 4.23 \\
\hline SF & 48.4 & $2,661.0^{\star \star}$ & 34.9 & $108.76 \pm 0.004$ & 69 & 158.43 & 7.73 \\
\hline SS & 203.0 & $12,540^{\star *}$ & 109.0 & $276.07 \pm 0.002$ & 74 & 89.72 & 7.79 \\
\hline NC & 0.01 & $0.12952^{\star *}$ & 0.00763 & $2.86 \pm 0.538$ & 89 & 0.273 & 1.75 \\
\hline PC & 0.145 & $5.0937^{\star *}$ & 0.3254 & $17.91 \pm 0.086$ & 78 & 1.707 & 1.83 \\
\hline SC & 0.002 & $1.3464^{\star *}$ & 0.0077 & $2.70 \pm 0.165$ & 68 & 0.932 & 6.45 \\
\hline OC & 0.04 & $151.24^{\star \star}$ & 0.88 & $21.23 \pm 0.016$ & 74 & 9.882 & 3.89 \\
\hline
\end{tabular}

MS = means square; $h^{2}=$ heritability; $\mathrm{GA}=$ genetic advance; $\mathrm{CV}=$ coefficient of variability. For other abbreviations see Table 4.

The estimates of heritability ranged from $68 \%$ (sucrose content) to $99 \%$ (plant height). The values of genetic advance varied from $158.43 \%$ for stomatal frequency to 0.87 for biological yield. The coefficient of variability (CV) was in the range 1.43 to 7.79 (Table 5).

\section{Genotypic and phenotypic correlations}

The correlation analysis was performed to identify mutual relationships among the various characters and also the type and extent of their contribution to yield (Panhwar et al., 2003; Chaudhary and Joshi, 2005). The genotypic and phenotypic correlations found here among the thirteen characters in plants grown under normal irrigation are summarized in Table 6.

Positive and significant genotypic correlations were observed between pairs of traits, e.g., LA and PH. Likewise, positive and highly significant phenotypic correlations were observed, e.g., LA and PH. Genotypically, NKE was significant and positively correlated with PH and LA; phenotypically, NKE showed a positive and highly significant correlation with LA but a positive and non-significant correlation with $\mathrm{PH}$. Genotypically, TGW was significantly and positively correlated with $\mathrm{PH}$ and LA but significantly and negatively correlated with NKE; phenotypically, TGW was positively and highly significantly correlated with $\mathrm{PH}$, but positively and non-significantly correlated with LA and negatively and non-significantly correlated with NKE. Genotypically, BY was significantly and positively correlated with $\mathrm{PH}$ and LA, but negatively and significantly correlated with NKE and TGW; phenotypically, BY was positively and highly significantly correlated with LA, positively and non-significantly correlated with $\mathrm{PH}$, but non-significantly correlated with NKE and TGW. Genotypically, GYP was significantly and positively correlated with PH, LA, NKE, TGW, and BY; phenotypically, GYP was positively and highly significantly correlated with PH, LA, and TGW, 


\begin{tabular}{|c|c|c|c|c|c|c|c|c|c|c|c|c|c|}
\hline & $\mathrm{PH}$ & LA & NKE & TGW & BY & GYP & $\mathrm{HI}$ & SF & SS & NC & PC & SC & OC \\
\hline PH G & 1.0000 & $0.6080^{*}$ & $0.0502^{*}$ & $0.4477^{\star}$ & $0.0507^{*}$ & $0.6015^{*}$ & $0.1920^{*}$ & $0.0502^{*}$ & $0.0181^{*}$ & $0.1854^{*}$ & $0.1892^{*}$ & $0.2613^{*}$ & $0.3223^{*}$ \\
\hline$P$ & 1.0000 & $0.6033^{\star *}$ & 0.0498 & $0.4420^{\star \star}$ & 0.0501 & $0.5963^{\star \star}$ & 0.1906 & 0.0491 & 0.0185 & 0.1830 & 0.1859 & $0.2587^{\star \star}$ & 0.3195 \\
\hline LA G & & 1.0000 & $0.2727^{\star}$ & $0.1449^{\star}$ & $0.2236^{*}$ & $0.5440^{*}$ & $0.0107^{\star}$ & $0.0356^{*}$ & $0.0348^{*}$ & 0.0209 & $0.0175^{*}$ & $0.4527^{\star}$ & 0.0015 \\
\hline $\mathrm{P}$ & & 1.0000 & $0.2709^{* *}$ & 0.1453 & $0.2213^{* *}$ & $0.5393^{\star \star}$ & 0.0107 & -0.0353 & 0.0349 & -0.0188 & -0.0158 & $0.4502^{\star *}$ & 0.0012 \\
\hline NKE G & & & 1.0000 & $0.0228^{*}$ & $0.0250^{*}$ & $0.1135^{\star}$ & $-0.0667^{\star}$ & $0.1437^{*}$ & $0.1284^{*}$ & $0.2490^{*}$ & $0.2489^{*}$ & $0.4138^{*}$ & $0.0588^{*}$ \\
\hline P & & & 1.0000 & -0.0226 & 0.0244 & 0.1137 & -0.0662 & -0.1427 & -0.1273 & 0.2414 & $0.2410^{* *}$ & $-0.4108^{\star *}$ & -0.0586 \\
\hline TGWG & & & & 1.0000 & $-0.0330^{*}$ & $0.2766^{\star}$ & $0.0316^{*}$ & $0.1403^{*}$ & $-0.0776^{\star}$ & $0.3385^{*}$ & $0.3439^{*}$ & $0.0296^{*}$ & $0.0885^{*}$ \\
\hline$P$ & & & & 1.0000 & -0.0321 & $0.2744^{\star \star}$ & 0.0312 & 0.1413 & -0.0777 & $0.3266^{\star \star}$ & $0.3300^{* *}$ & 0.0292 & 0.0871 \\
\hline BY G & & & & & 1.0000 & $0.0874^{*}$ & $-0.5755^{*}$ & $0.4702^{*}$ & $-0.1390^{*}$ & $0.0378^{*}$ & $0.0412^{*}$ & $-0.0267^{*}$ & $0.0966^{*}$ \\
\hline $\mathrm{P}$ & & & & & 1.0000 & 0.0867 & $-0.5729^{\star *}$ & $-0.4663^{\star *}$ & -0.1377 & 0.0398 & 0.0397 & 0.0279 & 0.0961 \\
\hline GYP G & & & & & & 1.0000 & $0.5313^{*}$ & $0.0697^{\star}$ & $0.2074^{\star}$ & $0.1857^{*}$ & $0.1909^{*}$ & $0.1746^{*}$ & $0.0135^{*}$ \\
\hline $\mathrm{P}$ & & & & & & 1.0000 & $0.5286^{\star *}$ & -0.0688 & $-0.2062^{\star \star}$ & $0.1809^{*}$ & $0.1832^{*}$ & $-0.1733^{*}$ & -0.0135 \\
\hline HI G & & & & & & & 1.0000 & $-0.3528^{*}$ & $0.0644^{*}$ & 0.0818 & $0.0829^{*}$ & $0.0613^{*}$ & 0.0810 \\
\hline $\mathrm{P}$ & & & & & & & 1.0000 & $-0.3491^{\star *}$ & -0.0629 & 0.0791 & 0.0819 & 0.0594 & 0.0813 \\
\hline SF G & & & & & & & & 1.0000 & $-0.0763^{*}$ & -0.0162 & -0.0127 & $0.3023^{*}$ & $-0.0815^{*}$ \\
\hline $\mathrm{P}$ & & & & & & & & 1.0000 & -0.0765 & -0.0166 & -0.0153 & $0.2997^{\star *}$ & -0.0814 \\
\hline SS G & & & & & & & & & 1.0000 & $0.0869^{*}$ & $0.0957^{*}$ & $-0.1352^{*}$ & $-0.0800^{*}$ \\
\hline $\mathrm{P}$ & & & & & & & & & 1.0000 & 0.0888 & 0.0894 & -0.1355 & -0.0787 \\
\hline $\mathrm{NCG}$ & & & & & & & & & & 1.0000 & $1.0637^{*}$ & -0.0562 & 0.0630 \\
\hline$P$ & & & & & & & & & & 1.0000 & $0.9999^{\star *}$ & -0.0531 & 0.0614 \\
\hline$P C G$ & & & & & & & & & & & 1.0000 & -0.0539 & $0.0564^{*}$ \\
\hline $\mathrm{P}$ & & & & & & & & & & & 1.0000 & -0.0534 & 0.0619 \\
\hline$S C G$ & & & & & & & & & & & & 1.0000 & $0.2194^{*}$ \\
\hline $\mathrm{P}$ & & & & & & & & & & & & 1.0000 & $0.2177^{\star *}$ \\
\hline OC G & & & & & & & & & & & & & 1.0000 \\
\hline$P$ & & & & & & & & & & & & & 1.0000 \\
\hline
\end{tabular}

For abbreviations, see Table 4. *Statistically significant. **Highly significant.

and positively and non-significantly correlated with NKE and BY. Genotypically, HI was significantly and positively correlated with PH, LA, TGW, and GYP, and significantly and negatively correlated with NKE and BY; phenotypically, HI was positively and highly significant correlated with GYP but negatively and highly significantly correlated with $\mathrm{BY}$, and positively and non-significantly correlated with LA and TGW, negatively and non-significantly correlated with NKE, and significantly and positively correlated with $\mathrm{PH}$. Genotypically, SF was significantly and negatively correlated with $\mathrm{PH}, \mathrm{LA}, \mathrm{NKE}, \mathrm{GYP}$, and HI, positively and significantly correlated with TGW and BY; phenotypically, SF was negatively and non-significantly correlated with PH, LA, NKE, and GYP, positively and non-significantly correlated with TGW, positively and highly significantly with BY, and negatively and highly significantly correlated with HI. Genotypically, SS was significantly and negatively correlated with NKE, TGW BY, GYP, HI, and SF, but significantly and positively correlated with PH and LA; phenotypically, SS was positively and non-significantly correlated with $\mathrm{PH}$ and LA, nonsignificantly and negatively correlated with NKE, TGW, BY, HI, and SF, and highly significantly and negatively correlated with GYP. Genotypically, NC was significant and positively correlated with $\mathrm{PH}, \mathrm{NKE}, \mathrm{TGW}, \mathrm{BY}, \mathrm{GYP}$, and SS, negatively and non-significantly with LA and SF, and positively and non-significantly with $\mathrm{HI}$; phenotypically, NC was positively and non-significantly correlated with NKE and TGW, positively and significantly correlated with PH and GYP, and positively and non-significantly correlated with $\mathrm{BY}, \mathrm{HI}$, and SS, but negatively and non-significantly correlated with LA and SF. Genotypically, PC was significantly and positively correlated with PH, NKE, TGW, $\mathrm{BY}, \mathrm{GYP}, \mathrm{HI}, \mathrm{SS}$, and $\mathrm{NC}$, negatively and significantly correlated with LA, and negatively and nonsignificantly correlated with SF. Phenotypically, PC was positively and highly significantly correlated with NKE, TGW, and NC, positively and significantly correlated with PH and GP, negatively and 
non-significantly correlated with LA and SF, positively and non-significantly correlated with BY, $\mathrm{HI}$, and SS. Genotypically, SS was significantly and negatively correlated with PH, LA, NKE, BY, and GYP, significantly and positively correlated with TGW, HI, and SF, and non-significantly and negatively correlated with NC; phenotypically, SS was negatively and highly significantly correlated with $\mathrm{PH}, \mathrm{LA}$, and NKE, positively and non-significantly correlated with TGW and HI, positively and non-significantly correlated with BY, SS, and NC. Phenotypically, SS was negatively and significantly correlated with GYP but positively and highly significantly correlated with SF. Genotypically, OC was positively and significantly correlated with $\mathrm{PH}, \mathrm{TGW}, \mathrm{HI}, \mathrm{PC}$, and SC, significantly and negatively correlated with NKE, BY, GYP, SF, and SS. OC was negatively and non-significantly correlated with LA, positively and non-significantly correlated with NC. Phenotypically, OC was positively and highly significantly correlated with $\mathrm{PH}$ and SC, negatively and non-significantly correlated with LA, NKE, BY, GYP, SF, and SS, and positively and non-significantly correlated with TGW, HI, NC, and PC.

\section{PCA}

The first six components, with eigen values $>1$, contributed $82.30 \%$ of the variability among the genotypes under the normal irrigation conditions (Table 7). The other PCs (7-13) had eigen values less than 1 .

\begin{tabular}{|c|c|c|c|c|c|c|}
\hline & PC1 & PC2 & PC3 & PC4 & PC5 & PC6 \\
\hline Eigen-values & 2.969 & 1.989 & 1.926 & 1.653 & 1.138 & 1.025 \\
\hline Proportion of variance & 22.837 & 15.297 & 14.812 & 12.718 & 8.755 & 7.883 \\
\hline Cumulative variance & 22.837 & 38.134 & 52.946 & 65.664 & 74.420 & 82.302 \\
\hline \multicolumn{7}{|l|}{ Variables } \\
\hline $\mathrm{PH}$ & 0.7631 & 0.0598 & 0.2603 & 0.3325 & 0.3022 & 0.1132 \\
\hline LA & 0.6110 & 0.0270 & 0.6491 & -0.0224 & 0.1428 & 0.0060 \\
\hline NKE & 0.3717 & -0.0607 & 0.1247 & -0.5758 & -0.3814 & 0.3567 \\
\hline TGW & 0.5092 & -0.2438 & -0.1678 & 0.3626 & 0.1205 & -0.1002 \\
\hline $\mathrm{BY}$ & -0.0148 & -0.7369 & 0.4629 & 0.0936 & -0.0730 & -0.0042 \\
\hline GYP & 0.7405 & 0.1931 & 0.2374 & 0.3029 & -0.2481 & -0.2836 \\
\hline $\mathrm{HI}$ & 0.3532 & 0.7065 & -0.3076 & 0.2224 & -0.2055 & -0.2727 \\
\hline SF & -0.1890 & -0.6742 & 0.1568 & 0.3791 & -0.0433 & -0.2041 \\
\hline SS & -0.0301 & 0.0305 & -0.1251 & -0.3441 & 0.8222 & -0.2763 \\
\hline NC & 0.5980 & -0.4254 & -0.6163 & -0.2187 & -0.0370 & -0.0276 \\
\hline PC & 0.6007 & -0.4248 & -0.6153 & -0.2163 & -0.0359 & -0.0291 \\
\hline SC & -0.4072 & -0.1209 & -0.4344 & 0.6221 & -0.0982 & -0.0198 \\
\hline OC & 0.1467 & 0.1019 & -0.2005 & 0.4307 & 0.2592 & 0.7744 \\
\hline
\end{tabular}

For abbreviations, see Table 4.

The first PC (PC1) was more related to the characters PH, GYP, LA, PC, NC, TGW, NKE, HI, and OC whereas PC2 was related to HI, GP, OC, PH, SS, and LA. PC3 was related to LA, BY, PH, GYP, SF, and NKE; PC4 showed some variability in its relationships to the characters SC, OC, SJ, TW, $\mathrm{PH}, \mathrm{GYP}, \mathrm{HI}$, and BY; for PC5, the parameters SS, PH, OC, and LA showed more diversity; PC6 was more related to OC, NKE, PH, and LA. SS exhibited the greatest positive weight with PC5 (Table 7).

\section{Cluster analysis}

The relationships of genotypes V1 to V54 (Tables 1 to 3 ) are shown as a dendrogram based on the 13 characters for plants grown under normal conditions (Figure 1). The $1600 \%$ level 
of similarity was only found for V53 which showed complete dissimilarity to the other genotypes. V21 and V23 showed approximately 380\% similarity, while V45 and V46 had 70\% similarity. V15 and V20 exhibited a $60 \%$ level of similarity. Very few genotypes fell into the similarity range 50 to $2020 \%$; most genotypes exhibited levels of similarity between 60 and $340 \%$ (Figure 1).

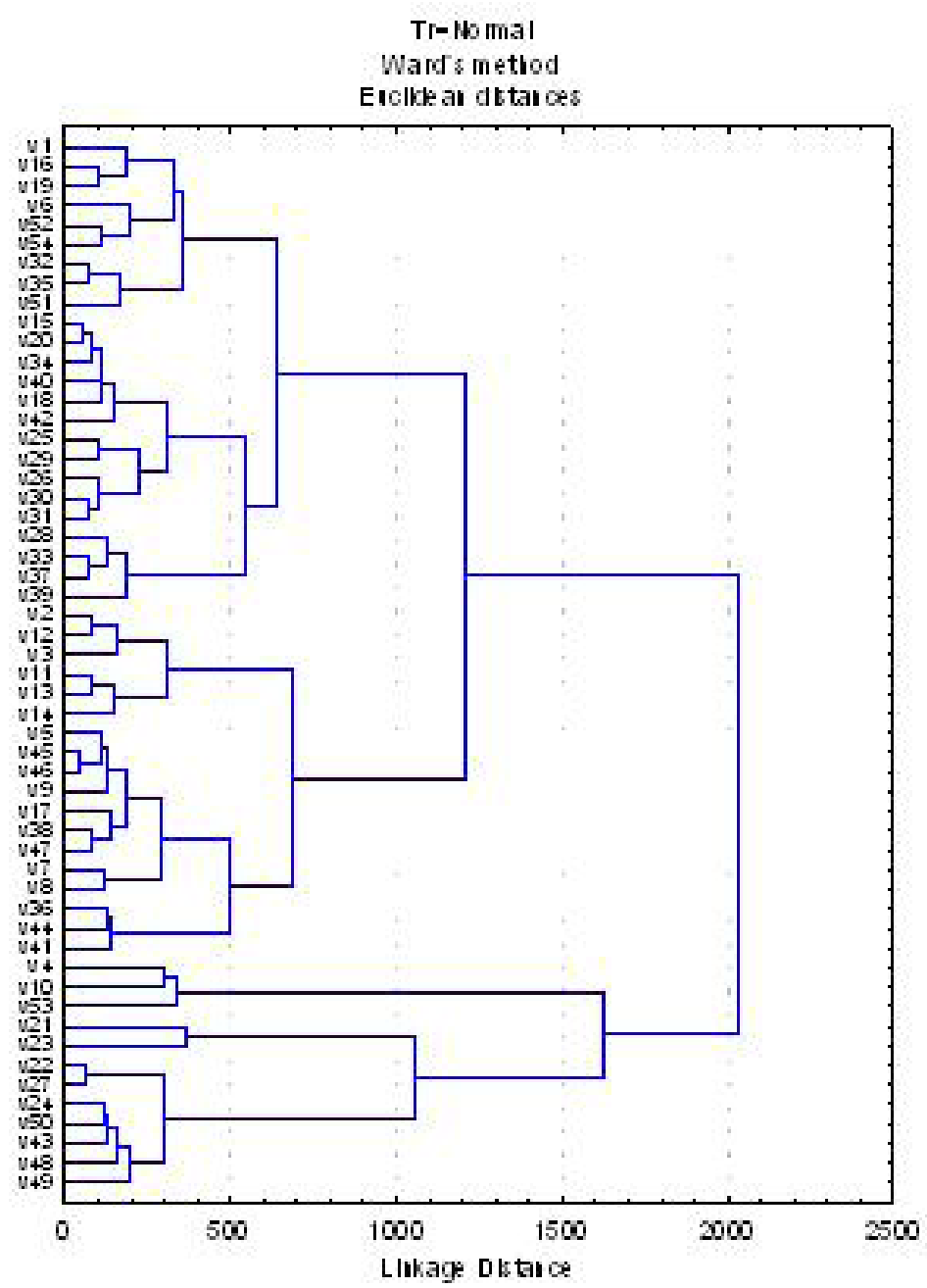

Figure 1. Dendrogram of 54 genotypes of Zea mays L. produced by single linkage cluster analysis of plants under normal irrigation conditions.

\section{Heritability estimates in plants grown under water stress conditions}

Heritability estimates ranged between 67 and $99 \%$ for the characters sucrose content and leaf area, respectively (Table 8 ). Values of genetic advance ranged from 153.41 for stomatal frequency to 0.47 for nitrogen content. The $\mathrm{CV}$ ranged from 1.52 to 7.38 . 
Table 8. Means and analysis of variance of the 13 characters in 54 genotypes under drought conditions.

\begin{tabular}{|c|c|c|c|c|c|c|c|}
\hline Parameters & MS (R) & $\mathrm{MS}(\mathrm{V})$ & MS (E) & Mean \pm SE & $h^{2}$ & GA & CV (\%) \\
\hline $\mathrm{PH}$ & 1.5 & $4573.8^{* *}$ & 34.9 & $125.003 \pm 0.003$ & 97 & 1.41 & 1.52 \\
\hline LA & 75 & $18902^{\star *}$ & 139.0 & $296.17 \pm 0.001$ & 99 & 2.31 & 2.30 \\
\hline NKE & 105 & $13256^{\star *}$ & 72.0 & $197.56 \pm 0.002$ & 81 & 0.95 & 3.78 \\
\hline TGW & 0 & $10858^{\star \star}$ & 71.0 & $210.58 \pm 0.002$ & 87 & 2.11 & 4.65 \\
\hline BY & 96 & $15737^{* \star}$ & 73.0 & $184.11 \pm 0.002$ & 89 & 0.76 & 3.89 \\
\hline GYP & 2.3 & $1200.2^{\star \star}$ & 3.2 & $39.46 \pm 0.006$ & 91 & 2.21 & 2.61 \\
\hline $\mathrm{HI}$ & 0.07 & $567.90^{\star *}$ & 1.51 & $23.59 \pm 0.008$ & 72 & 0.83 & 3.34 \\
\hline SF & 25.8 & $7054.7^{\star \star}$ & 27.1 & $132.97 \pm 0.002$ & 68 & 153.41 & 6.85 \\
\hline SS & 27 & $19745^{\star \star}$ & 165.0 & $302.48 \pm 0.001$ & 79 & 81.72 & 3.44 \\
\hline NC & 0.00383 & $0.49685^{\star *}$ & 0.01492 & $2.77 \pm 0.273$ & 87 & 0.47 & 2.54 \\
\hline PC & 0.061 & $17.681^{* *}$ & 0.515 & $17.38 \pm 0.046$ & 76 & 1.85 & 7.38 \\
\hline SC & 0.0001 & $1.1342^{\star \star}$ & 0.0098 & $2.22 \pm 0.179$ & 67 & 0.98 & 6.57 \\
\hline OC & 0.560 & $33.609^{\star \star}$ & 0.518 & $16.29 \pm 0.033$ & 76 & 4.613 & 3.551 \\
\hline
\end{tabular}

For abbreviations, see Table 4 and $5 .{ }^{* *}$ Highly significant.

The genotypic and phenotypic correlations observed here among the thirteen parameters in plants grown under $50 \%$ of normal irrigation or drought field condition are summarized in Table 9. Genotypically, LA was positively and significantly correlated with PH; phenotypically, LA was highly significantly and positively correlated with $\mathrm{PH}$. Genotypically, NKE was positively and significantly correlated with $\mathrm{PH}$ and LA, and was non-significantly and positively correlated with PH and LA. Genotypically, TGW was positively and significantly correlated with PH, LA, and NKE; phenotypically, it was highly significantly and positively correlated with $\mathrm{PH}$ but non-significantly correlated with LA and NKE. Genotypically, BY was positively and significantly correlated with $\mathrm{PH}$, LA, NKE, and TGW; phenotypically, BY was positively and highly significantly correlated with $\mathrm{PH}$, LA, NKE, and TGW. Genotypically, GYP was positively and significantly correlated with $\mathrm{PH}$, LA, NKE, TGW, and BY; phenotypically, GP was positively and highly significantly correlated with $\mathrm{PH}, \mathrm{LA}, \mathrm{TW}$, and BY but was positively and significantly correlated with NKE. Genotypically, HI was positively and significantly correlated with PH, LA, NKE, GW, BY, and YP; phenotypically, HI was positively and non-significantly correlated with $\mathrm{PH}, \mathrm{NKE}, \mathrm{TGW}$, and BY, negatively and nonsignificant correlated with LA, and positively and highly significantly correlated with GYP.

Genotypically, SF was significantly and negatively correlated with PH, LA, NKE, BY, GP, and $\mathrm{HI}$, and positively and significantly correlated with TGW; phenotypically, SF was negatively and non-significantly correlated with $\mathrm{PH}, \mathrm{LA}$, and $\mathrm{HI}$, negatively and highly significantly correlated with NKE and BY, positively and non-significantly correlated with TGW, negatively and highly significantly correlated with BY, and negatively and significantly correlated with GYP. Genotypically, SS was negatively and significantly correlated with $\mathrm{PH}, \mathrm{NKE}, \mathrm{TW}, \mathrm{BY}, \mathrm{GYP}$, and $\mathrm{HI}$, and positively and significantly correlated with LA and SF; phenotypically, SS was negatively and non-significantly correlated with $\mathrm{PH}, \mathrm{TGW}$, and $\mathrm{HI}$, was positively and non-significantly correlated with LA, and negatively and highly significantly correlated with NKE, BY, and GYP, and positively and highly significantly correlated with SF. Genotypically, NC was significantly and negatively correlated with PH, NKE, BY, GYP, and HI, positively and significantly correlated with LA, SF, and SS, and positively and non-significantly correlated with TGW. Phenotypically, NC was negatively and nonsignificantly correlated with $\mathrm{PH}$ and BY, was positively and non-significantly correlated with LA and TGW, was negatively and highly significantly correlated with NKE and GYP, and was significantly and positively correlated with SF and SS. Genotypically, PC was negatively and significantly correlated with $\mathrm{PH}, \mathrm{NKE}, \mathrm{BY}, \mathrm{GYP}$, and $\mathrm{HI}$, was negatively and non-significantly correlated with 


\begin{tabular}{|c|c|c|c|c|c|c|c|c|c|c|c|c|c|}
\hline & $\mathrm{PH}$ & LA & NKE & TGW & BY & GYP & $\mathrm{HI}$ & SF & SS & NC & PC & SC & $\mathrm{OC}$ \\
\hline PH G & 1.0000 & $0.6137^{\star}$ & $0.1195^{\star}$ & $0.3528^{*}$ & $0.3430^{*}$ & $0.5753^{*}$ & $0.0987^{\star}$ & $0.0815^{*}$ & $0.1274^{*}$ & $0.0711^{*}$ & $0.0652^{*}$ & $0.2446^{*}$ & $0.0710^{*}$ \\
\hline$P$ & 1.0000 & $0.6101^{* *}$ & 0.1185 & $0.3498^{\star \star}$ & $0.3408^{\star *}$ & $0.5725^{\star *}$ & 0.0976 & -0.0822 & -0.1261 & -0.0712 & -0.0631 & $-0.2420^{* *}$ & 0.0701 \\
\hline LA G & & 1.0000 & $0.0672^{*}$ & $0.1392^{*}$ & $0.2926^{*}$ & $0.4296^{*}$ & $-0.0175^{*}$ & $-0.0371^{*}$ & $0.1233^{*}$ & $0.0394^{*}$ & -0.0059 & $-0.3141^{*}$ & -0.0045 \\
\hline $\mathrm{P}$ & & 1.0000 & 0.0679 & 0.1387 & $0.2894^{* *}$ & $0.4273^{* *}$ & -0.0177 & -0.0374 & 0.1215 & 0.0403 & -0.0070 & $-0.3132^{\star *}$ & -0.0037 \\
\hline NKE G & & & 1.0000 & $0.0759^{*}$ & $0.2350^{*}$ & $0.1803^{*}$ & $0.0156^{*}$ & $-0.3609^{*}$ & $-0.2885^{*}$ & $-0.4425^{\star}$ & $-0.4315^{\star}$ & $-0.1969^{*}$ & $-0.2511^{*}$ \\
\hline$P$ & & & 1.0000 & 0.0756 & $0.2344^{\star *}$ & $0.1800^{*}$ & 0.0153 & $-0.3590^{\star *}$ & $-0.2865^{\star \star}$ & $-0.4325^{\star \star}$ & $-0.4261^{* *}$ & $-0.1954^{*}$ & $-0.2484^{* *}$ \\
\hline TGWG & & & & 1.0000 & $0.2565^{\star}$ & $0.2415^{\star}$ & $0.0280^{*}$ & $0.1011^{*}$ & $-0.1134^{\star}$ & 0.0057 & 0.0100 & $-0.0588^{*}$ & $0.1038^{*}$ \\
\hline $\mathrm{P}$ & & & & 1.0000 & $0.2539^{\star *}$ & $0.2400^{* *}$ & 0.0281 & 0.1021 & -0.1140 & 0.0050 & 0.0129 & -0.0598 & 0.1026 \\
\hline BY G & & & & & 1.0000 & $0.5040^{*}$ & $0.0564^{*}$ & $-0.2083^{*}$ & $-0.3130^{*}$ & $-0.1299^{\star}$ & $-0.0743^{*}$ & $-0.3479^{*}$ & $0.0333^{*}$ \\
\hline $\mathrm{P}$ & & & & & 1.0000 & $0.5018^{* *}$ & 0.0554 & $-0.2082^{* *}$ & $-0.3115^{\star \star}$ & -0.1290 & -0.0777 & $-0.3439^{\star *}$ & 0.0311 \\
\hline GYP G & & & & & & 1.0000 & $0.6442^{*}$ & $-0.1648^{*}$ & $-0.3086^{*}$ & $-0.2258^{\star}$ & $-0.2196^{\star}$ & $-0.2926^{*}$ & $-0.2204^{*}$ \\
\hline $\mathrm{P}$ & & & & & & 1.0000 & $0.6429^{\star *}$ & $-0.1648^{*}$ & $-0.3071^{* \star}$ & $-0.2223^{\star \star}$ & $-0.2160^{\star *}$ & $-0.2911^{\star *}$ & $-0.2194^{* *}$ \\
\hline HI G & & & & & & & 1.0000 & $-0.0538^{*}$ & $-0.1485^{*}$ & $-0.1243^{*}$ & $-0.1464^{*}$ & -0.0332 & $-0.2451^{*}$ \\
\hline $\mathrm{P}$ & & & & & & & 1.0000 & -0.0528 & -0.1462 & -0.1212 & -0.1442 & -0.0332 & -0.2434 \\
\hline SF G & & & & & & & & 1.0000 & $0.2909^{*}$ & $0.4044^{*}$ & $0.4019^{*}$ & $0.3355^{\star}$ & $0.1329^{*}$ \\
\hline $\mathrm{P}$ & & & & & & & & 1.0000 & $0.2901^{\text {** }}$ & $0.3979^{\star *}$ & $0.3972^{\star \star}$ & $0.3329^{\star \star}$ & 0.1314 \\
\hline SS G & & & & & & & & & 1.0000 & $0.3336^{\star}$ & $0.2779^{*}$ & $0.1430^{*}$ & $-0.0414^{*}$ \\
\hline $\mathrm{P}$ & & & & & & & & & 1.0000 & $0.3270^{\star *}$ & $0.2754^{\star \star}$ & 0.1429 & -0.0405 \\
\hline $\mathrm{NCG}$ & & & & & & & & & & 1.0000 & $0.9844^{\star}$ & 0.2239 & 0.1137 \\
\hline$P$ & & & & & & & & & & 1.0000 & $0.9549^{\star *}$ & $0.2212^{\star *}$ & 0.1105 \\
\hline$P C G$ & & & & & & & & & & & 1.0000 & $0.2461^{*}$ & $0.2028^{*}$ \\
\hline$P$ & & & & & & & & & & & 1.0000 & $0.2401^{\text {** }}$ & $0.2004^{*}$ \\
\hline$S C G$ & & & & & & & & & & & & 1.0000 & $0.2198^{*}$ \\
\hline$P$ & & & & & & & & & & & & 1.0000 & $0.2191^{\text {** }}$ \\
\hline OC G & & & & & & & & & & & & & 1.0000 \\
\hline$P$ & & & & & & & & & & & & & 1.0000 \\
\hline
\end{tabular}

For abbreviations, see Table 4. *Statistically significant. **Highly significant.

LA, was positively and non-significantly correlated with TGW, and was positively and significantly correlated with SF, SS, and NC. Phenotypically, PC was negatively and non-significantly correlated with PH, LA, BY, and HI, was negatively and highly significantly correlated with NKE and GYP, was positively and highly significantly correlated with SF and NC, and was non-significantly and positively correlated with TGW. Genotypically, SS was significantly and negatively correlated with $\mathrm{PH}, \mathrm{LA}, \mathrm{NKE}, \mathrm{TGW}, \mathrm{BY}$, and GYP, was negatively and non-significantly correlated with HI, was positively and significantly correlated with SF, SS, and PC, and was positively and non-significantly correlated with NC. Phenotypically, SS was negatively and highly significantly correlated with PH, LA, BY, and GYP, was negatively and significantly correlated with NKE, was negatively and nonsignificantly correlated with TGW and HI, was positively and highly significantly correlated with SF, NC, and PC, and was positively and non-significantly correlated with SS. Genotypically, OC was positively and significantly correlated with $\mathrm{PH}, \mathrm{TGW}, \mathrm{BY}, \mathrm{SF}, \mathrm{PC}$, and SS, was negatively and non-significantly correlated with LA, was negatively and significantly correlated with NKE, GYP, $\mathrm{HI}$, and SS, and was positively and non-significantly correlated with NC. Phenotypically, OC was positively and non-significantly correlated with $\mathrm{PH}, \mathrm{TGW}, \mathrm{BY}, \mathrm{SF}$, and NC, was negatively and non-significantly correlated with LA and SS, was negatively and highly significantly correlated with NKE, GYP, and HI, was positively and highly significantly correlated with SS, and was positively and significantly correlated with PC.

\section{PCA}

The first four components, with eigen values $>1$, contributed $64.79 \%$ (Table 10) of the variability among genotypes under drought conditions. The other PCs (5-13) had eigen values less than 1 . 


\begin{tabular}{|c|c|c|c|c|}
\hline & PC1 & PC2 & PC3 & PC4 \\
\hline Eigen-values & 3.568 & 2.237 & 1.388 & 1.231 \\
\hline Proportion of variance & 27.446 & 17.206 & 10.674 & 9.468 \\
\hline Cumulative variance & 27.446 & 44.652 & 55.326 & 64.794 \\
\hline \multicolumn{5}{|l|}{ Variables } \\
\hline $\mathrm{PH}$ & 0.5207 & -0.6287 & -0.1485 & 0.0344 \\
\hline LA & 0.3773 & -0.6163 & -0.1606 & 0.4416 \\
\hline NKE & 0.5665 & 0.3119 & -0.1733 & 0.0661 \\
\hline TGW & 0.2346 & -0.4307 & -0.2011 & -0.4073 \\
\hline BY & 0.5655 & -0.3600 & -0.2238 & -0.1342 \\
\hline GYP & 0.7335 & -0.4298 & 0.4170 & -0.1265 \\
\hline $\mathrm{HI}$ & 0.3596 & -0.0907 & 0.8186 & -0.2470 \\
\hline SF & -0.5388 & -0.3484 & 0.1751 & -0.1725 \\
\hline SS & -0.5008 & -0.1644 & 0.1035 & 0.5514 \\
\hline NC & -0.6643 & -0.5721 & 0.1151 & 0.0897 \\
\hline $\mathrm{PC}$ & -0.6618 & -0.5742 & 0.0586 & 0.0016 \\
\hline SC & -0.5469 & 0.0912 & 0.1380 & -0.4556 \\
\hline OC & -0.2682 & -0.2068 & -0.5460 & -0.4690 \\
\hline
\end{tabular}

For abbreviations, see Table 4.

PC1 was more related to GYP, NKE, BY, PH, LA, HI, and TGW, whereas, PC2 was related to NKE and SC. PC3 was more related to HI, GYP, SF, SC NC, SS, and PC, while PC4 showed more variability for SS, LA NKE, NC, PH, and PC. For PC3, HI exhibited the greatest positive weight (Table 10).

\section{Cluster analysis}

The relationships of genotypes V1 to V54 (Tables 1 to 3 ) are shown as a dendrogram based on the 13 characters in plants grown under drought stress (Figure 2). The $230 \%$ level of similarity was shown only by $\mathrm{V} 1$ and $\mathrm{V} 23$ indicating total dissimilarity to the rest of the genotypes. V29 and V33 showed similarity at the 125\% level, while V30 and V31 showed $35 \%$ similarity. V45 and V46 had a $36 \%$ level of similarity. Few genotypes fell into the similarity range 525 to $1600 \%$; most genotypes showed levels of similarity in the range 100 to $600 \%$ (Figure 2).

\section{ANOVA in plants under normal irrigation conditions}

ANOVA for the 13 characters measured here in plants grown under normal irrigation is shown in Table 11. The analysis showed that there were no significant differences between the replicate experiments for any of the characters. By contrast, all the other comparisons for varieties, parents, parents $x$ crosses $(P \times C)$ interaction, crosses, lines, testers, lines $x$ testers $(L \times T)$ interaction, and pooled error were highly significant different with one exception; only the NKE character in the $\mathrm{P} \times \mathrm{C}$ interaction was non-significant. These results showed that both inbred lines and testers were significantly different from one another in crosses, that the inbred lines behaved differently in their respective crosses, and that greater diversity existed among the four testers. The $L x T$ interaction term was significant for all the studied traits, suggesting that inbred lines may have different combining abilities and that they performed differently in crosses depending on the type of tester used. Similar results were reported by Aly and Hassan (2011) and Mousa and Aly (2011). 


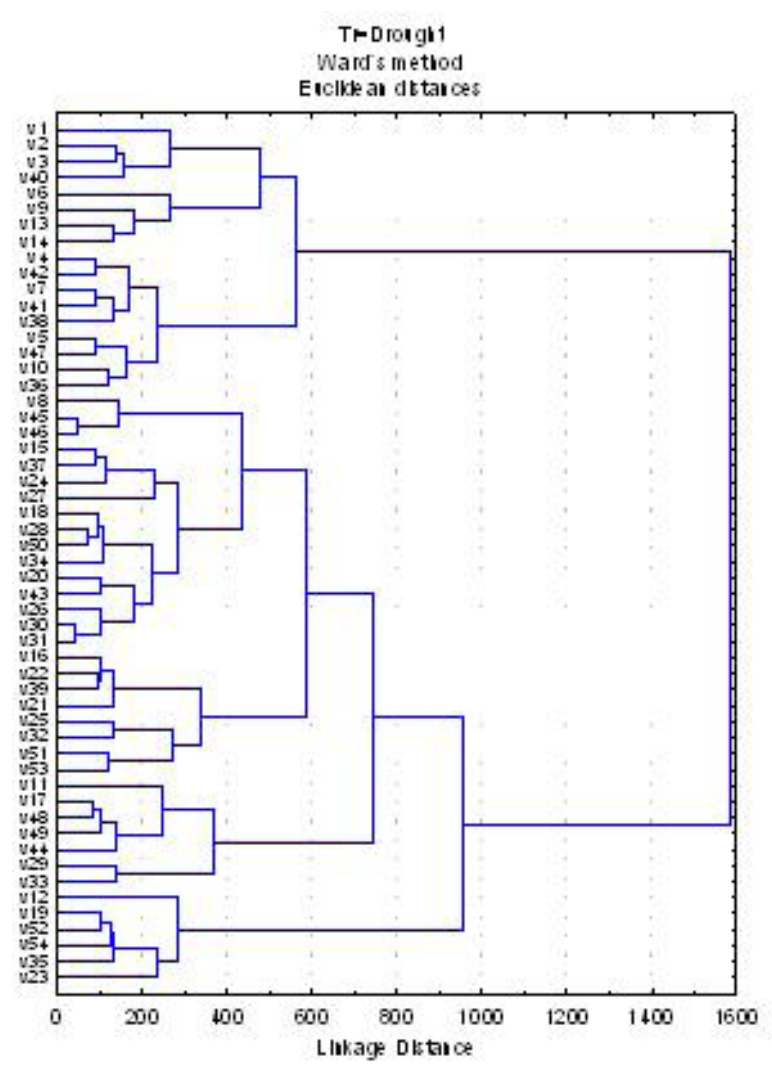

Figure 2. Dendrogam of the 54 genotypes of Zea mays L. produced by single linkage cluster analysis of plants grown under water stress.

\section{Estimates of general combining ability (GCA) effects under normal irrigation conditions}

GCA for the ten inbred lines and four testers was evaluated under normal irrigation conditions (Table 12). The results indicated that inbred lines $L_{10}, L_{8}$, and $L_{7}$ showed highly significant and negative GCA effects for $\mathrm{PH}$ towards dwarfness of plants; lines $L_{7}$ and $L_{6}$ showed highly significant and negative GCA effects for $L A$ toward lower leaf size; lines $L_{2}, L_{3}$, and $L_{9}$ had highly significant and positive GCA effects for NKE towards an increase in NKE, which is an important yield component; lines $L_{6}$ and $L_{1}$ gave highly significant and positive GCA effects for TGW compared to other lines with non-significant and negative GCA effects. Line $L_{10}$ showed a highly negative GCA effect for BY while other lines showed highly significant and negative GCA effects; $L_{10}$ and $L_{5}, L_{2}$, and $L_{3}$ showed highly significant and positive GCA effects while only $L_{1}$ showed non-significant results for GYP. The inbred lines $L_{6}$ and $L_{9}$ showed highly significant and negative GCA effects toward lowering $S F$; inbred lines $L_{10}, L_{5}$, and $L_{7}$ showed highly significant and negative GCA effects towards a decrease in SF; only inbred line $L_{2}$ showed a highly significant and positive GCA effect for both NC and PC. For SC, $L_{7}$ and $L_{5}$ showed highly significant and positive GCA effects. Lines $L_{1}$ and $L_{5}$ showed highly significant and positive GCA effects for OC. 
The analyses summarized in Table 12 indicate that $\mathrm{T}_{4}$ was the best general combiner for $\mathrm{PH}$ and $\mathrm{LA}$. $\mathrm{T}_{1}$ and $\mathrm{T}_{4}$ were the best combiners for NKE showing highly significant and positive GCA values. $T_{2}$ was a good combiner for TGW, while tester $T_{3}$ was a good combiner for BY. $T_{2}$ and $\mathrm{T}_{4}$ had highly positive and significant GCA effects for GYP towards an increase in yield; $\mathrm{T}_{4}$ was also a good combiner for H1. $\mathrm{T}_{1}$ was the best combiner for the traits SF and SS towards a decrease in SF and SS. $T_{2}$ was a good combiner for NC and PC. $T_{4}$ was the best combiner for $\mathrm{SC}$ and $\mathrm{OC}$.

Table 11. Analysis of variance for the 13 characters under normal irrigation conditions.

\begin{tabular}{|c|c|c|c|c|c|c|c|c|c|c|c|c|c|c|}
\hline Source & d.f & $\mathrm{PH}$ & LA & NKE & TGW & BY & GYP & $\mathrm{HI}$ & SF & SS & NC & PC & SC & $\mathrm{OC}$ \\
\hline Reps & 2 & $33^{\text {ns }}$ & $58^{\text {ns }}$ & $352.5^{\text {ns }}$ & $189.0^{\text {ns }}$ & $93^{\text {ns }}$ & $10.5^{\text {ns }}$ & $2.87^{\text {ns }}$ & $48.43^{\text {ns }}$ & $203.3^{\text {ns }}$ & $0.011123^{\text {ns }}$ & $0.0145^{\mathrm{ns}}$ & $0.00214^{\mathrm{ns}}$ & $0.039^{\text {ns }}$ \\
\hline Varts & 53 & $4486^{* \star}$ & $34219^{* *}$ & $42854.5^{\star \star}$ & $7620.4^{\star \star *}$ & 59580 ** & $1380.4^{\star \star}$ & $440.25^{\star \star}$ & $2661.04^{\star *}$ & $12540.3^{* *}$ & $0.129519^{\star *}$ & $5.0937^{* *}$ & $1.34643^{\text {** }}$ & $151.235^{\star \star}$ \\
\hline Parents & 13 & $2714^{\star *}$ & $8447^{\star \star}$ & $21978.8^{\star \star}$ & $20763.6^{\star \star}$ & $128883^{\star \star}$ & $1182.7^{\star \star}$ & $1110.11^{\star *}$ & $5072.16^{\star \star}$ & $3039.6^{\star \star}$ & $0.218255^{\star \star}$ & $8.6265^{\star \star}$ & $1.11742^{\star \star}$ & $148.282^{\star \star}$ \\
\hline$P \times C$ & 1 & $122176^{\star \star}$ & $675396^{\star \star}$ & $676.0^{\text {ns }}$ & $29433.4^{\star *}$ & $1757^{\star \star}$ & $25676.7^{\star \star}$ & $963.41^{\star \star}$ & $9840.94^{\star *}$ & $9238.3^{\star \star}$ & $0.076707^{\star \star}$ & $3.1090^{\star \star}$ & $8.00722^{\star \star}$ & $287.381^{\star \star}$ \\
\hline Crosses & 39 & $2060^{* \star}$ & $26369^{\star *}$ & $50894.5^{\star \star}$ & $2680.0^{* *}$ & $37961^{\star *}$ & $823.3^{\star *}$ & $203.55^{\star \star}$ & $1673.23^{\text {** }}$ & $15791.9^{* *}$ & $0.101295^{\star \star}$ & $3.9670^{\star \star}$ & $1.25197^{\star \star}$ & $148.729^{* \star}$ \\
\hline Lines & 9 & $2963^{* \star}$ & $49049^{* *}$ & $49880.0^{* *}$ & $2177.8^{* *}$ & $87154^{* *}$ & $1159.9^{* *}$ & $244.59^{\star \star}$ & $1132.57^{* *}$ & $25640.9^{* *}$ & $0.101085^{\star \star}$ & $3.9356^{\star \star}$ & $1.93360^{* *}$ & $138.742^{\star \star}$ \\
\hline Testers & 3 & $657^{\star \star}$ & $6511^{\star \star}$ & $15451.9^{\star \star}$ & $4106.8^{\star *}$ & $7481^{\star \star}$ & $1039.9^{\star \star}$ & $155.68^{\star \star}$ & $589.92^{\star *}$ & $25665.1^{\text {** }}$ & $0.258467^{\star \star}$ & $10.0199^{* \star}$ & $0.27809^{\star \star}$ & $46.825^{\star \star}$ \\
\hline$L x T$ & 27 & $1914^{\star \star}$ & $21015^{\star \star}$ & $55170.8^{\star \star *}$ & $2688.9^{\star \star}$ & 24950 ** & $687.0^{\star *}$ & $195.19^{* \star}$ & $1973.81^{* *}$ & $11411.9^{\star *}$ & $0.083901^{* \star}$ & $3.3049^{\star \star}$ & $1.13297^{\star *}$ & $163.381^{\star \star}$ \\
\hline Error & 106 & $45^{\star \star}$ & $217^{\star \star}$ & $221.1^{\star \star}$ & $96.1^{\star \star}$ & $250^{\star \star}$ & $8.2^{* \star}$ & $2.31^{\star \star}$ & $34.86^{\star \star}$ & $109.0^{* \star}$ & $0.007628^{\star \star}$ & $0.3254^{* \star}$ & $0.00768^{\star \star}$ & $0.884^{\star \star}$ \\
\hline
\end{tabular}

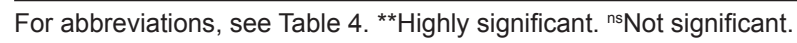

Table 12. Estimates of general combining ability effects for the 13 characters in the inbred lines used for line $x$ tester crosses under normal irrigation conditions.

\begin{tabular}{|c|c|c|c|c|c|c|c|c|c|c|c|c|c|}
\hline Line & $\mathrm{PH}$ & LA & NKE & TGW & BY & GYP & $\mathrm{HI}$ & SF & SS & NC & PC & SC & $\mathrm{OC}$ \\
\hline L1 & $21.43^{* *}$ & $-63.223^{\star *}$ & $21.151^{\star *}$ & $18.3524^{\star *}$ & $-28.200^{\star *}$ & $3.0319^{*}$ & $3.7820^{\star *}$ & $7.4974^{\star \star}$ & $12.7775^{\star *}$ & $0.091417^{*}$ & $0.57317^{*}$ & $0.67875^{\star}$ & $2.225^{\star \star}$ \\
\hline L2 & $19.68^{* *}$ & $31.952^{\star \star}$ & $119.038^{* \star}$ & $7.9524^{\star}$ & $11.800^{*}$ & $7.0369^{\star \star}$ & $0.4395^{\mathrm{ns}}$ & $0.5974^{\mathrm{ns}}$ & $-9.3625^{*}$ & $0.146417^{\star *}$ & $0.91317^{* \star}$ & $-0.37125^{\star *}$ & $-0.400^{\text {ns }}$ \\
\hline L3 & $-10.72^{\star \star}$ & $70.162^{\star \star}$ & $49.776^{\star \star}$ & $-7.2976^{\star}$ & $8.050^{\text {ns }}$ & $7.0869^{\star *}$ & $-0.1730^{\text {ns }}$ & $-5.1776^{\star}$ & $-62.9600^{* \star}$ & $-0.03108^{\text {ns }}$ & $-0.19183^{\text {ns }}$ & $-0.15875^{\star *}$ & $-2.525^{\star \star}$ \\
\hline L4 & $9.53^{*}$ & $36.980^{* *}$ & $-91.337^{\star *}$ & $-8.0726^{*}$ & $14.300^{*}$ & $5.6494^{\star *}$ & $-1.4330^{*}$ & $11.6724^{\star *}$ & $3.8225^{\mathrm{ns}}$ & $-0.180250^{\star}$ & $-1.12850^{* *}$ & $-0.16625^{\star *}$ & $-5.025^{\star *}$ \\
\hline L5 & 10.93 & $-5.295^{\star}$ & $-38.537^{\star \star}$ & $23.7774^{\star}$ & $-13.700^{*}$ & $8.8644^{\star *}$ & $5.2470^{\star \star}$ & $-7.3276^{\star *}$ & $-37.4000^{\star \star}$ & $0.031417^{\mathrm{ns}}$ & $0.19817^{\text {ns }}$ & $0.24625^{\star *}$ & $6.100^{\star \star}$ \\
\hline L6 & $-10.47^{\star}$ & $-67.445^{\star \star}$ & $-53.037^{\star \star}$ & $3.7774^{\text {ns }}$ & $-52.700^{\star \star}$ & $-10.5306^{\star \star}$ & $0.2220^{\mathrm{ns}}$ & $-13.577^{\star \star}$ & $52.8900^{\star \star}$ & $-0.00108^{\text {ns }}$ & $-0.00433^{\text {ns }}$ & $0.19875^{\star \star}$ & $-4.900^{\star \star}$ \\
\hline L7 & $3.98^{\star}$ & $-71.938^{\star \star}$ & $-68.662^{\star \star}$ & $-15.4726^{\star \star}$ & $-85.700^{\star \star}$ & $-11.1056^{* *}$ & $5.7095^{\star \star}$ & $3.6724^{\star}$ & $-25.6450^{\star \star}$ & $-0.051083^{\star}$ & $-0.31683^{\text {ns }}$ & $0.25875^{\star \star}$ & $1.975^{\star \star}$ \\
\hline L8 & $-25.67^{\star \star}$ & $-35.440^{\star \star}$ & $2.088^{\mathrm{ns}}$ & $-10.4468^{*}$ & $-58.200^{\star \star}$ & $-13.1123^{\star *}$ & $-0.8955^{\star}$ & $-6.0526^{\star}$ & $61.4958^{\star \star}$ & $0.016417^{\mathrm{ns}}$ & $0.10317^{\text {ns }}$ & $0.06125^{\star}$ & $0.725^{\mathrm{ns}}$ \\
\hline L9 & $-2.57^{\text {ns }}$ & $119.342^{\star \star}$ & $54.096^{\star \star}$ & $-13.6226^{* *}$ & $-19.450^{\star \star}$ & $-9.4056^{\star \star}$ & $-3.0805^{\star \star}$ & $-7.9776^{\star \star}$ & $58.5650^{\star *}$ & $-0.076083^{*}$ & $-0.47183^{*}$ & $-0.79125^{\star \star}$ & $0.850^{\text {ns }}$ \\
\hline L10 & $-16.12^{\star \star}$ & $-15.095^{\star}$ & $5.422^{\mathrm{ns}}$ & $1.0524^{\mathrm{ns}}$ & $223.801^{\star \star}$ & $12.4844^{* *}$ & $-9.8180^{\star \star}$ & $16.6733^{* \star}$ & $-54.1833^{\star \star}$ & $0.053917^{\star}$ & $0.32567^{\star}$ & $0.04375^{\mathrm{ns}}$ & $0.975^{*}$ \\
\hline S.E lines & 1.946 & 4.25 & 4.3 & 2.830 & 4.6 & 0.828 & 0.4388 & 1.704 & 3.01 & 0.0252133 & 0.16466 & 0.025305 & 0.2714 \\
\hline T1 & $2.40^{\mathrm{ns}}$ & $19.305^{\star *}$ & $10.657^{\star \star}$ & $4.5674^{*}$ & $5.2999^{\text {ns }}$ & $1.1898^{*}$ & $0.3295^{\mathrm{ns}}$ & $-6.6226^{* *}$ & $-39.6900^{\star *}$ & $-0.12708^{\star *}$ & $-0.79183^{\star \star}$ & $-0.10825^{\star *}$ & $-0.325^{\star *}$ \\
\hline T2 & $4.70^{*}$ & $-4.984^{\text {ns }}$ & $-31.702^{\star \star}$ & $11.6174^{\star *}$ & $-1.600^{\text {ns }}$ & $4.7984^{\star *}$ & $0.4805^{\mathrm{ns}}$ & 2.7774 * & $15.460^{\star *}$ & $0.095917^{\star \star}$ & $0.59617^{\star *}$ & $-0.02225^{\mathrm{ns}}$ & $-1.475^{\star \star}$ \\
\hline T3 & $-1.04^{\text {ns }}$ & $1.529^{\text {ns }}$ & $20.651^{\star *}$ & $-0.2222^{\text {ns }}$ & $17.000^{\star *}$ & $-8.5446^{\star \star}$ & $-3.1345^{\star \star}$ & $2.0374^{\text {ns }}$ & $27.2583^{\star *}$ & $0.017917^{\mathrm{ns}}$ & $0.1125^{\text {ns }}$ & $0.00575^{\mathrm{ns}}$ & $0.275^{\star \star}$ \\
\hline T4 & $-6.06^{\star *}$ & $-15.8493^{\star \star}$ & $* 0.393^{\text {ns }}$ & $-15.9626^{\star \star}$ & $-20.700^{\star \star}$ & $2.5564^{\star \star}$ & $2.3245^{\star \star}$ & $1.8077^{\mathrm{ns}}$ & $-3.0287^{\mathrm{ns}}$ & $0.01325^{\mathrm{ns}}$ & $0.08317^{\mathrm{ns}}$ & $0.12475^{\star \star}$ & $1.525^{\star \star}$ \\
\hline S.E tester & 1.231 & 2.69 & 2.7 & 1.790 & 2.9 & 0.524 & 0.2775 & 1.078 & 1.91 & 0.0159463 & 0.10414 & 0.016004 & 0.1716 \\
\hline S.E (gi-gj) tester & 1.508 & 3.29 & 3.3 & 2.192 & 3.5 & 0.642 & 0.3399 & 1.320 & 2.33 & 0.0195301 & 0.12755 & 0.019601 & 0.2102 \\
\hline
\end{tabular}

For abbreviations, see Table 4. *Statistically significant. **Highly significant. ns Not significant.

\section{Estimates of specific combining ability (SCA) effects under normal irrigation conditions}

For $\mathrm{PH}$, both negative and positive, significant and non-significant estimates of SCA effects were present among the crosses (Table 13). Crosses $L_{3} \times T_{4}, L_{6} \times T_{2}$, and $L_{9} \times T_{1}$ were good specific combiners whereas crosses $\mathrm{L}_{8} \times \mathrm{T}_{1}, \mathrm{~L}_{9} \times \mathrm{T}_{4}$, and $\mathrm{L}_{6} \times \mathrm{T}_{1}$ were poor specific combiners (Table 13). Smaller plants can be advantageous for resistance to lodging. With regard to the parameter $\mathrm{PH}$, the estimates of SCA effects were found to be significant in 30 of the 40 crosses evaluated in the current study.

With respect to $L A$, crosses $L_{2} \times T_{1}, L_{4} \times T_{2}$, and $L_{3} \times T_{4}$ possessed highly significant 
and negative SCA values indicating they were good specific combiners. The crosses $L_{10} \times T_{3}$, $L_{8} \times T_{1}$, and $L_{9} \times T_{2}$ were the poorest specific combiners. The estimates of SCA were significant in 28 of 40 crosses. Plants with a lower leaf area are at an advantage under water stress conditions.

For NKE, crosses $L_{2} \times T_{3}, L_{3} \times T_{1}$, and $L_{7} \times T_{2}$ were good specific combiners, while crosses $L_{3} \times T_{3}, L_{7} \times T_{1}$, and $L_{6} \times T_{3}$ were the poorest. Only 31 of 40 crosses showed a significant result for this trait.

For TGW, crosses $L_{2} \times T_{1}, L_{1} \times T_{2}$, and $L_{9} \times T_{4}$ showed high positive and significant SCA effects showing they were good combiners; crosses $L_{6} \times T_{4}, L_{8} \times T_{1}$, and $L_{2} \times T_{3}$ were the poorest specific combiners.

With respect to $B Y$, crosses $L_{10} \times T_{3}, L_{5} \times T_{2}$, and $L_{6} \times T_{1}$ exhibited high significant and positive SCA effects indicating they were good specific combiners; $L_{10} \times T_{4}, L_{10} \times T_{2}$, and $L_{3} \times T_{3}$ were the poorest specific combiners for BY.

For GYP, crosses $L_{10} \times T_{3}, L_{9} \times T_{4}$, and $L_{7} \times T_{4}$ were good specific combiners and crosses $L_{8}$ $x T_{4}, L_{10} \times T_{2}$, and $L_{7} \times T_{1}$ were the poorest.

Only 5 crosses were found to exhibit a non-significant level of SCA for SF (Table 13), showing that most of the crosses evaluated in the current study significantly deviated from what would have been predicted based on parental performance. Crosses $L_{5} \times T_{4}, L_{7} \times T_{1}$, and $L_{1} \times T_{4}$ were good specific combiners for $S F$ while crosses $L_{1} \times T_{2}, L_{2} \times T_{4}$, and $L_{6} \times T_{1}$ were poor specific combiners (Table 13).

For $S S$, the crosses $L_{3} \times T_{1}, L_{6} \times T_{3}$, and $L_{6} \times T_{1}$ were good specific combiners and $L_{4} \times T_{1}, L_{5}$ $x T_{1}$, and $L_{7} x T_{4}$ were poor. For this trait, 32 of 40 crosses exhibited highly significant SCA effects.

Twenty of the 40 crosses gave a significant level of SCA for NC. Crosses $L_{9} \times T_{4}, L_{8} \times T_{3}$, and $L_{4} \times T_{2}$ were good specific combiners while $L_{8} \times T_{1}, L_{4} \times T_{4}$, and $L_{7} \times T_{1}$ were poor.

For PC, 18 of the 40 crosses exhibited a significant level of SCA effects (Table 13). The crosses $L_{9} \times T_{4}, L_{8} \times T_{3}$, and $L_{7} \times T_{2}$ were good specific combiners while $L_{9} \times T_{3}, L_{8} \times T_{1}$, and $L_{7} \times T_{2}$ were poor.

For $S C$, crosses $L_{5} \times T_{3}, L_{9} \times T_{1}$, and $L_{3} \times T_{4}$ showed highly significant and positive SCA effects and proved to be a good specific combiners while the poorest specific combiners were $L_{2} x$ $\mathrm{T}_{3}, \mathrm{~L}_{5} \times \mathrm{T}_{1}$, and $\mathrm{L}_{10} \times \mathrm{T}_{1}$.

With respect to $O C$, crosses $L_{5} \times T_{4}, L_{3} \times T_{3}$, and $L_{8} \times T_{1}$ were good specific combiners while crosses $L_{5} \times T_{4}, L_{6} \times T_{4}$, and $L_{1} \times T_{3}$ were the poorest.

\section{ANOVA in plants grown under water stress}

ANOVA of the 13 characters measured in plants grown under water stress conditions is shown in Table 14. No significant differences were found between replicate experiments for any trait. The parents, $\mathrm{P} \times \mathrm{C}$ interactions, crosses, lines, testers, $\mathrm{L} \times \mathrm{T}$ interaction, and pooled error terms were all highly significant with two exceptions: the $\mathrm{P} \times \mathrm{C}$ interaction for $\mathrm{SS}$ and $\mathrm{PC}$ were nonsignificant indicating that the crosses used for the current study had comparable potentials for the traits SS and PC. Overall, the results of the ANOVA indicated that the inbred lines and testers were significantly different from each other in crosses, and that the inbred lines showed differences in their respective crosses, and that more diversity existed among the four testers. For all characters studied, the $L x T$ interactions were significant suggesting that the inbred lines might possess different combining abilities depending on the type of tester used in the cross. 


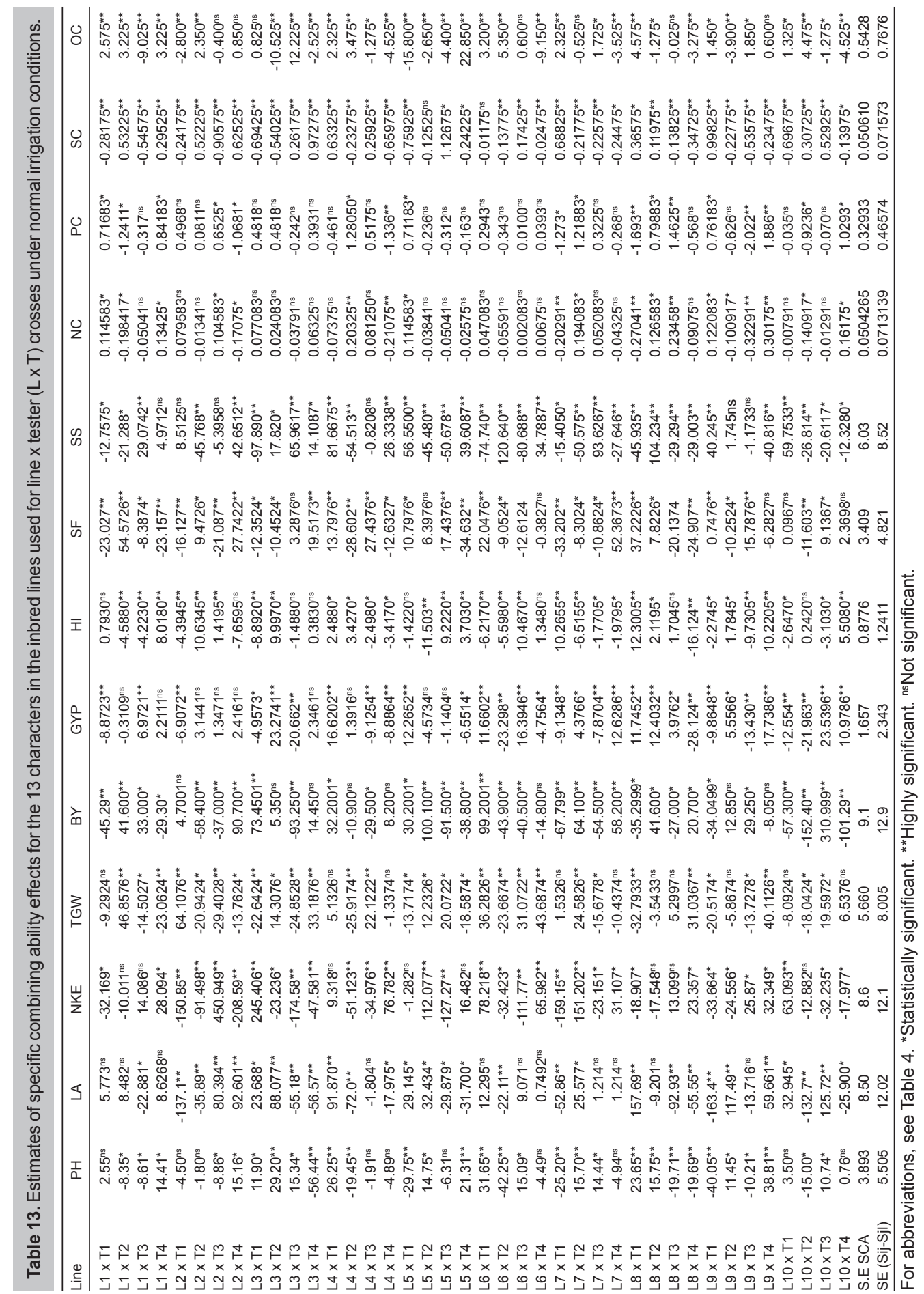




\section{Estimates of GCA effects under water stress}

The GCA for the 10 inbred lines and four testers were evaluated under water stress conditions. The analysis showed that the inbred lines $L_{8}, L_{7}$, and $L_{9}$ had highly significant GCA effects on $\mathrm{PH}$ towards shorter plants. Lines $\mathrm{L}_{7} \mathrm{~L}_{8}$, and $\mathrm{L}_{6}$ showed highly significant and negative GCA effects for $L A$ towards lower leaf size. Lines $L_{8}, L_{3}$, and $L_{9}$ had highly significant and positive GCA effects for NKE towards an increase in NKE. Lines $L_{1}$ and $L_{6}$ displayed highly significant and positive GCA effects for TGW towards an increase in TGW. All inbred lines except $L_{3}$ and $L_{4}$ showed highly significant results for $B Y: L_{10}$ and $L_{3}$ had highly positive and significant results, while $L_{7}$ and $\mathrm{L}_{8}$ had highly negative and significant results toward a decrease in BY. For $\mathrm{HI}$, a yield contributing character, the inbred lines $L_{6}, L_{4}$, and $L_{5}$ showed highly positive and significant results towards high $\mathrm{HI}$. For $S F$, lines $\mathrm{L}_{8}$ and $\mathrm{L}_{3}$ showed highly negative and significant values indicating increased fitness for drought or water stress conditions. Only three lines, $L_{6}, L_{9}$, and $L_{10}$, showed negative and non-significant GCA values for SF, the remainder showed significant or highly significant effects. For $S S$, lines $L_{10}, L_{3}$, and $L_{2}$ had highly negative and significant GCA values toward a decrease in $S S$, indicating greater fitness for water stress conditions. Lines $L_{9}$ and $L_{7}$ showed highly positive and significant GCA values for NC towards an increase in the nutritional value of maize. For PC, lines $L_{9}, L_{10}$, and $L_{7}$ showed highly positive and significant GCA values toward an increase in PC. For SC, all ten inbred lines showed significant results but only $L_{7}, L_{8}$, and $L_{10}$ had positive and significant GCA values. For OC, $\mathrm{L}_{1}, \mathrm{~L}_{8}$, and $\mathrm{L}_{10}$ gave highly positive and significant GCA effects.

The testers $T_{2}$ and $T_{3}$ were the best general combiners for $\mathrm{PH}$ and $\mathrm{LA}$ (Table 15). $\mathrm{T}_{1}$ and $\mathrm{T}_{4}$ were the best general combiners for biochemical characters affecting yield, such as NKE, TGW, SC, and OC. $T_{1}$ was a good combiner for TGW, $T_{1}$, and $T_{2}$ for $B Y ; T_{2}$ and $T_{3}$ were good combiners for GYP; $T_{1}$ was a good combiner for $\mathrm{HI}$, and, along with $\mathrm{T}_{4}$, for SF and SS. $\mathrm{T}_{2}$ and $\mathrm{T}_{3}$ were better combiners for NC and PC.

Table 14. Analysis of variance for the 13 characters in plants grown under water stress.

\begin{tabular}{|c|c|c|c|c|c|c|c|c|c|c|c|c|c|c|}
\hline Source & d.f & $\mathrm{PH}$ & LA & NKE & TGW & BY & GYP & $\mathrm{HI}$ & SF & SS & NC & PC & SC & OC \\
\hline & 2 & & & & & & & & & & & & & \\
\hline & 53 & $74^{\star \star}$ & * & & 857 & & *** & & & & & & & \\
\hline rents & 13 & $305^{\star \star}$ & & & ${ }^{* \star}$ & & & & & & & & & \\
\hline xC & 1 & $128421^{\star *}$ & & & & & & & & & & & & \\
\hline & 39 & & & & & & & & & & & & & \\
\hline & 9 & & $92^{\star \star}$ & & $88.4^{\star *}$ & & & & & & & & & $25.7644^{\star \star}$ \\
\hline Testers & 3 & $28^{\star *}$ & $55^{\star \star}$ & $11229.8^{* \star}$ & $339.7^{\star \star}$ & $3501.8^{* *}$ & $1046.0^{* \star}$ & $226.58^{\star \star}$ & & $49155.6^{\star \star}$ & $0.281654^{\star \star}$ & $15.7549^{\star \star}$ & $0.38539^{\star \star}$ & $29.5103^{\star \star}$ \\
\hline & 27 & & & & & & & & & & & & & \\
\hline Error & 106 & $35^{\star \star}$ & $139^{\star *}$ & $71.8^{\star \star}$ & $71.3^{\star *}$ & $73.1^{\text {** }}$ & $3.2^{\star \star}$ & $1.51^{\star \star}$ & $27.1^{\star *}$ & $164.5^{\star \star}$ & $0.014919^{\star *}$ & $0.5147^{\star \star}$ & $0.00983^{\star *}$ & $0.5184^{\star \star}$ \\
\hline
\end{tabular}

For abbrevitaions, see Table $4 .{ }^{*}$ Statistically significant. ${ }^{*}$ Highly significant. ns Not significant.

\section{Estimates of SCA effects under water stress conditions}

We evaluated the SCA of the 40 crosses for the thirteen parameters in plants grown under water stress conditions (Table 16). For $\mathrm{PH}$, the crosses $\mathrm{L}_{6} \times T_{2}, \mathrm{~L}_{3} \times \mathrm{T}_{3}$ and $\mathrm{L}_{9} \times \mathrm{T}_{1}$ showed highly significant and negative SCA effects and were good specific combiners; the crosses $L_{2} \times T_{2}, L_{4} \times T_{1}$ and $L_{3} \times T_{2}$ showed highly significant and positive SCA effects and were poor specific combiners for this trait. 
Table 15. Estimates of general combining ability effects for the 13 characters in the inbred lines used for line $x$ tester crosses under water stress.

\begin{tabular}{|c|c|c|c|c|c|c|c|c|c|c|c|c|c|}
\hline Line & $\mathrm{PH}$ & LA & NKE & TGW & BY & GYP & $\mathrm{HI}$ & SF & SS & NC & PC & SC & $\mathrm{OC}$ \\
\hline L1 & $30.89^{\star *}$ & $9.7982^{*}$ & $-14.964^{\star *}$ & $16.300^{\star *}$ & $7.700^{\star}$ & $6.9405^{\star \star}$ & $1.09575^{\star}$ & $-21.332^{\star *}$ & $4.9267^{\text {ns }}$ & $0.093417^{\star}$ & $0.4830^{\star}$ & $0.137917^{\star *}$ & $1.13817^{\star *}$ \\
\hline L2 & $-6.01^{\star}$ & $-7.5767^{\star}$ & $-45.214^{\star \star}$ & $-20.77^{\star \star}$ & $7.701^{\star}$ & $-5.3195^{\star \star}$ & $-4.3117^{\star \star}$ & $-11.082^{\star \star}$ & $-30.2633^{\star \star}$ & $-0.039083^{\text {ns }}$ & $-0.3445^{\text {ns }}$ & $-0.448750^{\star \star}$ & $0.76233^{\star}$ \\
\hline L3 & $-0.46^{\text {ns }}$ & $58.1108^{\star *}$ & $42.2858^{\star *}$ & $3.150^{\text {ns }}$ & $25.201^{\star \star}$ & $11.4055^{\star \star}$ & $0.95075^{*}$ & $-12.907^{\star *}$ & $-47.7608^{\star \star}$ & $-0.054083^{\text {ns }}$ & $-0.4395^{\star}$ & $-0.294583^{\star *}$ & $-0.23767^{\mathrm{ns}}$ \\
\hline L4 & $17.19^{\star \star}$ & $69.0108^{* *}$ & $1.4533^{\mathrm{ns}}$ & $-3.275^{\mathrm{ns}}$ & $-4.800^{\star}$ & $10.3930^{\star *}$ & $5.27325^{\star \star}$ & $20.4425^{\star *}$ & $37.4517^{\star \star}$ & $0.030917^{\mathrm{ns}}$ & $0.0930^{\text {ns }}$ & $-0.432083^{\star *}$ & $-1.11267^{\star *}$ \\
\hline L5 & $7.69^{\star}$ & $12.1733^{*}$ & $11.5358^{\star \star}$ & $6.500^{\star}$ & $-11.050^{\star \star}$ & $6.9780^{\star \star}$ & $3.21325^{\star \star}$ & $73.9925^{\star *}$ & $-7.3682^{\text {ns }}$ & $-0.109083^{\star}$ & $-0.7820^{\star}$ & $0.200417^{\star \star}$ & $-3.11183^{\star *}$ \\
\hline L6 & $9.39^{\star \star}$ & $-23.764^{\star \star}$ & $-22.156^{\star \star}$ & $15.475^{\star \star}$ & $-36.050^{\star \star}$ & $1.3655^{\star}$ & $9.09075^{\star \star}$ & $-2.2575^{\mathrm{ns}}$ & $7.5142^{*}$ & $-0.205750^{\star \star}$ & $-1.3920^{\star *}$ & $0.187917^{\star \star}$ & $0.26233^{\text {ns }}$ \\
\hline L7 & $-18.71^{\star *}$ & $-75.026^{\star \star}$ & $-80.214^{\star \star}$ & $-6.600^{*}$ & $-62.300^{\star *}$ & $-11.094^{\star *}$ & $1.49325^{\star \star}$ & $7.9175^{\star \star}$ & $-4.2308^{\text {ns }}$ & $0.103417^{*}$ & $0.5455^{\star}$ & $0.472917^{\star \star}$ & $1.01233^{* *}$ \\
\hline L8 & $-28.01^{* *}$ & $-26.901^{\star \star}$ & $75.9533^{\star \star}$ & $-11.47^{* \star}$ & $-36.050^{\star *}$ & $-12.462^{\star *}$ & $-3.5742^{\star *}$ & $-50.507^{\star \star}$ & $29.3342^{\star *}$ & $0.045917^{\text {ns }}$ & $0.1830^{\text {ns }}$ & $0.405417^{\star \star}$ & $1.38733^{\star *}$ \\
\hline L9 & $-12.96^{\star \star}$ & $-15.339^{\star \star}$ & $27.7858^{\star \star}$ & $-6.400^{*}$ & $-17.300^{\star \star}$ & $-18.902^{\star \star}$ & $-6.2567^{\star \star}$ & $-1.6825^{\text {ns }}$ & $69.6142^{\star \star}$ & $0.208417^{\star \star}$ & $0.8755^{\star \star}$ & $-0.444583^{\star *}$ & $-1.36267^{\star *}$ \\
\hline L10 & $0.99^{\text {ns }}$ & $-0.4842^{\text {ns }}$ & $3.5358^{\text {ns }}$ & $7.100^{*}$ & $126.950^{\star *}$ & $10.6955^{\star \star}$ & $-6.9742^{\star *}$ & $-2.5825^{\mathrm{ns}}$ & $-59.2183^{\star \star}$ & -0.07 & $0.7780^{*}$ & $17^{\star \star}$ & $1.26233^{\star *}$ \\
\hline S.E Lines & 1.705 & 3.41 & 2.45 & 2.44 & 2.47 & 0.516 & 0.354 & 1.50 & 3.70 & 0.035260 & 0.20710 & 0.028619 & 0.2078 \\
\hline T1 & $7.00^{* \star}$ & $19.503^{* \star}$ & $15.9108^{\star \star}$ & $11.555^{\star *}$ & $9.200^{\star *}$ & $8 . .5155^{\star \star}$ & $3.5542^{\star \star}$ & $-20.422^{\star \star}$ & $-43.6748^{\star *}$ & -0.124083 & $-0.8760^{* *}$ & $-0.090083^{\star *}$ & $-0.88733^{\star *}$ \\
\hline T2 & $-2.18^{\star}$ & $-14.906^{\star \star}$ & $1.7028^{\text {ns }}$ & $-0.345^{\mathrm{ns}}$ & $-5.0998^{*}$ & $-0.7085^{*}$ & $-0.6628^{*}$ & $4.6575^{\star \star}$ & $-2.710^{\text {ns }}$ & 0.054917 & $0.7790^{\star \star}$ & $-0.041083^{*}$ & $-0.13767^{\text {ns }}$ \\
\hline T3 & $-10.70^{\star \star}$ & $-4.7847^{\star}$ & $-27.672^{\star \star}$ & $-1.275^{\mathrm{ns}}$ & $8.6998^{* \star}$ & * $-4.6475^{\star \star}$ & $-3.0897^{\star \star}$ & $19.9675^{\star \star}$ & $54.216^{\star \star}$ & 0.09525 & $0.3620^{*}$ & $-0.03475^{\text {ns }}$ & $1.41233^{\star \star}$ \\
\hline T4 & $5.88^{\star}$ & $0.1883^{\mathrm{ns}}$ & $10.0588^{\star \star}$ & $-9.935^{\star \star}$ & $-12.8002^{\star \star}$ & * $-3.1595^{\star \star}$ & $0.1983^{\text {ns }}$ & $-4.2025^{\star \star}$ & $-7.832^{*}$ & -0.026083 & $-0.2650^{\star}$ & $0.165917^{\star \star}$ & $-0.38733^{*}$ \\
\hline S.E tester & 1.078 & 2.15 & 1.55 & 1.54 & 1.56 & 0.326 & 0.224 & 0.95 & 2.34 & 0.022300 & 0.13098 & 0.018100 & 0.1315 \\
\hline S.E (gi-gj) te & er 1.320 & 2.64 & 1.89 & 1.89 & 1.91 & 0.400 & 0.275 & 1.16 & 2.87 & 0.027312 & 0.16042 & 0.022168 & 0.1610 \\
\hline
\end{tabular}

For abbrevitaions, see Table 4. *Statistically significant. **Highly significant. ns Not significant.

For $L A$, the crosses $L_{9} \times T_{1}, L_{2} \times T_{1}$ and $L_{3} \times T_{1}$ were good specific combiners whereas $L_{4}$ $\times T_{1}, L_{10} \times T_{1}$ and $L_{2} \times T_{2}$ were poor specific combiners. The crosses $L_{6} \times T_{1}, L_{3} \times T_{1}$ and $L_{7} \times T_{2}$ had highly significant and positive SCA effects and were good specific combiners for NKE, while $L_{1} \times T_{2}$, $L_{7} \times T_{1}$ and $L_{4} \times T_{3}$ had highly significant and negative SCA effects and were poor specific combiners.

For TGW, the crosses $L_{3} \times T_{2}, L_{2} \times T_{1}$ and $L_{6} \times T_{3}$ were good specific combiners while the crosses $L_{3} \times T_{1}, L_{2} \times T_{2}$, and $L_{2} \times T_{3}$ were poor specific combiners. For $B Y$, the crosses $L_{6} \times T_{1}, L_{9} \times T_{3}$ and $L_{7} \times T_{1}$ showed highly significant and positive SCA effects and were good specific combiners while the crosses $L_{9} \times T_{1}, L_{6} \times T_{2}$ and $L_{2} \times T_{2}$ showed highly significant and negative SCA effects and were poor specific combiners.

For GYP, the crosses $L_{10} \times T_{1}, L_{3} \times T_{2}$ and $L_{3} \times T_{4}$ were good specific combiners by showing high positive SCA effects while the crosses $L_{2} \times T_{4}, L_{1} \times T_{1}$ and $L_{9} \times T_{2}$ possess high negative SCA effects and were poor specific combiners. With respect to $H I$, the crosses $L_{9} \times T_{1}, L_{6} \times T_{4}$ and $L_{4} \times$ $T_{1}$ showed highly significant and positive SCA effects and were good specific combiners while the crosses $L_{6} \times T_{1}, L_{2} \times T_{4}$ and $L_{9} \times T_{2}$ had negative SCA effects and were poor specific combiners.

For SF, the crosses $L_{6} \times T_{3}, L_{9} \times T_{3}$ and $L_{4} \times T_{4}$ had highly significant and negative SCA effects and were good specific combiners whereas $L_{9} \times T_{1}, L_{5} \times T_{2}$, and $L_{4} \times T_{3}$ possessed highly significant and positive SCA effects and were poor specific combiners. For $S S$, the crosses $L_{7} \times T_{2}$, $L_{4} \times T_{4}$, and $L_{6} \times T_{3}$ resulted in highly significant and negative SCA effects and were good specific combiners, while the crosses $L_{8} \times T_{2}, L_{4} \times T_{3}$ and $L_{7} \times T_{1}$ showed highly significant and positive SCA effects and were poor specific combiners.

For $N C$, the crosses $L_{8} \times T_{1}, L_{10} \times T_{1}$ and $L_{6} \times T_{2}$ had highly significant and positive SCA effects and were good specific combiners whereas the crosses $L_{4} \times T_{4}, L_{10} \times T_{2}$ and $L_{5} \times T_{1}$ showed highly significant and negative SCA effects and were poor specific combiners. For PC, the crosses $L_{8} \times T_{1}, L_{3} \times T_{4}$, and $L_{4} \times T_{3}$ gave highly significant and positive SCA effects and were good specific combiners, whereas the crosses $L_{4} \times T_{4}, L_{8} \times T_{4}$ and $L_{5} \times T_{1}$ had highly significant and negative SCA effects and were poor specific combiners.

With regard to $S C$, the crosses $L_{3} \times T_{4}, L_{5} \times T_{3}$ and $L_{9} \times T_{1}$ gave highly significant and positive SCA effects and were good specific combiners while the crosses $L_{5} \times T_{1}, L_{3} \times T_{2}$ and $L_{4} \times T_{4}$ showed negative SCA effects and were poor specific combiners. In the case of OC, the crosses $L_{10} \times T_{2}, L_{1}$ $x T_{2}$ and $L_{2} \times T_{4}$ had highly significant and positive SCA effects and were good specific combiners 
whereas the crosses $L_{10} \times T_{3}, L_{1} \times T_{3}$ and $L_{4} \times T_{4}$ had highly significant and negative SCA effects and were poor specific combiners.

\begin{tabular}{|c|c|c|c|c|c|c|c|c|c|c|c|c|c|}
\hline Line & $\mathrm{PH}$ & LA & NKE & TGW & BY & GYP & $\mathrm{HI}$ & SF & SS & NC & PC & SC & $\mathrm{OC}$ \\
\hline $\mathrm{xT} 1$ & $-10.95^{*}$ & $7.222^{\mathrm{ns}}$ & $-0.1608^{\text {ns }}$ & $-4.880^{\text {ns }}$ & $-34.200^{\star *}$ & $-20.595^{\star \star}$ & $-6.7668^{\star \star}$ & $2.123^{\text {ns }}$ & $-13.212^{\text {ns }}$ & $0.221583^{*}$ & $1.4810^{*}$ & $-0.05991^{\mathrm{ns}}$ & $1.01150^{\star}$ \\
\hline $1 \times \mathrm{T} 2$ & & $-37.96^{\star *}$ & $-75.702^{\star \star}$ & $17.020^{*}$ & $20.099^{\star \star}$ & & $-3.6398^{\star \star}$ & $-4.3575^{\text {ns }}$ & $-31.978^{\star \star}$ & $-0.147417^{\star}$ & $-1.3540^{*}$ & & $5.76183^{* *}$ \\
\hline$-1 \times \mathrm{T} 3$ & $19.95^{\star \star}$ & * $33.109^{\star *}$ & $54.9222^{\star *}$ & $6.950^{\mathrm{ns}}$ & $6.3002^{\text {ns }}$ & $8.1475^{\star \star}$ & $2.91725^{\star \star}$ & $-15.967^{\star \star}$ & $22.096^{*}$ & $-0.09775^{\mathrm{ns}}$ & $-0.377^{\text {ns }}$ & $-0.31525^{\star \star}$ & $-4.28817^{\star \star}$ \\
\hline L1 $\times$ T4 & $13.37^{\star}$ & $-2.3632^{\text {ns }}$ & $20.9412^{\star \star}$ & $-19.090^{\star}$ & $7.8002^{\text {ns }}$ & $17.329^{\star \star}$ & $7.4892^{\star \star}$ & & $23.094^{\star}$ & $0.023583^{\mathrm{ns}}$ & $0.2500^{\text {ns }}$ & $0.084083^{\text {ns }}$ & $-2.48517^{\star \star}$ \\
\hline $\mathrm{L} 2 \times \mathrm{T} 1$ & $7.35^{\star}$ & $-87.30^{\star \star}$ & $40.3392^{\star *}$ & $69.195^{\star \star}$ & $35.799^{\star \star}$ & $11.6645^{\star \star}$ & $0.4207^{\text {ns }}$ & -19.82 & $-18.8828^{*}$ & $-0.195917^{\star}$ & & $126750^{*}$ & $-3.11267^{\star \star}$ \\
\hline $2 \times \mathrm{T} 2$ & $28.13^{\star \star}$ & * $58.306^{* *}$ & $54.5472^{\star *}$ & $-55.105^{\star \star}$ & $-49.897^{\star *}$ & $1.8885^{\text {ns }}$ & $7.9677^{\star \star}$ & & $-24.538^{*}$ & & & $50^{\star \star}$ & \\
\hline $\mathrm{L} 2 \times \mathrm{T} 3$ & $-38.75^{\star \star}$ & $-4.315^{\mathrm{ns}}$ & $-41.077^{\star \star}$ & & $-13.700^{*}$ & & & & & & $05^{\text {ns }}$ & & $-1.91233^{\star *}$ \\
\hline L2 2 T4 & $3.27^{\text {ns }}$ & 33.31 & -53.80 & $5^{\star \star}$ & $27.799^{\star \star}$ & $-28.500^{\star \star}$ & -16.513 & & & & & & $33^{\star \star}$ \\
\hline$-3 \times \mathrm{T} 1$ & $16.80^{* \star}$ & * $-82.99^{\star \star}$ & 92.83 & -84.73 & $18.302^{*}$ & & & & & & & & \\
\hline L3 $\times$ T2 & & & $-52.9 ?$ & 86.3 & & & & & & & & & $33^{* *}$ \\
\hline$-3 \times \mathrm{T} 3$ & -48.90 & & & & & & & & & & & & \\
\hline$-3 \times \mathrm{T} 4$ & & & & & & & & & & & & & \\
\hline L4 x T1 & 23.9 & $107.80^{\star \star}$ & -30 & & -41.70 & & & & 29.7 & & & $33^{\star \star}$ & $33^{* *}$ \\
\hline $4 \times \mathrm{T} 2$ & & & & & & & & & & & & & \\
\hline $4 \times \mathrm{T} 3$ & -17.7 & & & & & & & & & & & & \\
\hline L4 × T4 & -9.7 & & & & & & & & & & & & \\
\hline $\mathrm{L} 5 \times \mathrm{T} 1$ & & $27.947^{* *}$ & & & & & & & & & & & $7^{\text {** }}$ \\
\hline$-5 \times \mathrm{T} 2$ & -15.3 & & & & -1.1 & & $27^{\text {ns }}$ & & -55.2 & & & & \\
\hline $\mathrm{L} 5 \times \mathrm{T} 3$ & 19.5 & * -47.5 & -12.8 & & & & & & & & & & \\
\hline $\mathrm{L} 5 \times \mathrm{T} 4$ & $-5.83^{\text {ns }}$ & $6.5118^{\mathrm{ns}}$ & $-0.5588^{\text {ns }}$ & $20.410^{\star *}$ & $-23.449^{\star \star}$ & $-13.648^{\star \star}$ & $-4.2783^{\star \star}$ & $-30.422^{\star \star}$ & $9^{\star \star}$ & $33^{*}$ & $8250^{* *}$ & & $350^{\text {ns }}$ \\
\hline $6 \times \mathrm{T} 1$ & & ${ }^{*}-26$. & & & & & & & & & & & \\
\hline L6 x T2 & $-49.67^{\star \star}$ & * $2.1943^{\text {ns }}$ & $-38.510^{\star \star}$ & $5^{* \star}$ & -36.1 & & & $75^{\star \star}$ & & & $10^{\text {**}}$ & $83^{*}$ & $33^{*}$ \\
\hline L6 $\times$ T3 & $34.65^{\star \star}$ & $38.172^{\star \star}$ & & $47.775^{\star \star}$ & $-4.9498^{\text {ns }}$ & $14.1425^{\star \star}$ & $3.59225^{\star \star}$ & $-74.042^{\star \star}$ & $-89.551^{\star *}$ & & $-3.192^{\star \star}$ & & $-1.91233^{* *}$ \\
\hline $6 \times \mathrm{T} 4$ & & & & & & & & & & & & & \\
\hline$-7 \times \mathrm{T} 1$ & & -26 & & & & & & & $48^{\star \star}$ & & & & \\
\hline L7 $\times$ T2 & & & $59.5472^{\star *}$ & $320^{\star \star}$ & $30.0998^{\star \star}$ & 14.16 & & $7.0925^{\star}$ & $-109.40^{\star \star}$ & & -0.85 & $17^{\text {ns }}$ & $-0.11233^{\text {ns }}$ \\
\hline $7 \times \mathrm{T} 3$ & & & & & & & & & & & & & \\
\hline$\times \mathrm{T} 4$ & & & & & & & & & & & & & -0.3 \\
\hline$-8 \times T 1$ & $-23.85^{\star \star}$ & * $55.222^{\star \star}$ & & $-24.105^{\star \star}$ & $-40.450^{\star \star}$ & & & & $0^{\star *}$ & & & $83^{\star \star}$ & $-0.23767^{\text {ns }}$ \\
\hline $8 \times \mathrm{T} 2$ & & & & & & & & & & & & & \\
\hline $8 \times T 3$ & & $-48.69^{\star *}$ & & & & & & & & & & & $1.46267^{*}$ \\
\hline$-8 \times \mathrm{T} 4$ & & $-28.66^{\star \star}$ & & & & & & & $-23.323^{\star \star}$ & & & & $2.26233^{\star \star}$ \\
\hline$-9 \times \mathrm{T} 1$ & $-38.50^{\star \star}$ & * $-93.59^{\star *}$ & $-32.660^{\star \star}$ & $-20.380^{\star *}$ & $-89.200^{\star \star}$ & $7.9070^{\star \star}$ & $21.0257^{\star \star}$ & $72.772^{\star \star}$ & $77.5597^{\star \star}$ & $0.076583^{\text {ns }}$ & $0.9085^{\mathrm{ns}}$ & $0.922583^{\star \star}$ & $-0.48767^{\text {ns }}$ \\
\hline$-9 \times \mathrm{T} 2$ & & & & & & & & & & & & & \\
\hline$-9 \times$ T3 & & $473^{*}$ & $-4.0778^{\text {ns }}$ & $-8.550^{\text {ns }}$ & $71.3002^{\star \star}$ & $3400^{\star \star}$ & $602^{\star \star}$ & $517^{\star \star}$ & $-28.131^{*}$ & $0.06725^{\text {ns }}$ & $-0.329^{\text {ns }}$ & $-0.42275^{\star \star}$ & $3.21267^{\star \star}$ \\
\hline$-9 \times \mathrm{T} 4$ & $12.42^{*}$ & $14.0743^{*}$ & $47.1912^{\star \star}$ & $10.210^{*}$ & $12.8002^{*}$ & $3.7620^{\star}$ & $-3.3683^{\star \star}$ & & $-69.343^{\star \star}$ & $-0.04141^{\mathrm{ns}}$ & $0.1675^{\mathrm{ns}}$ & $-0.28341^{\star *}$ & $1.01233^{*}$ \\
\hline & $-12.65^{\star}$ & & & & & & & & & & & $-0.487417^{* *}$ & \\
\hline$-10 \times 12$ & $-4.47^{\text {ns }}$ & & & $-6.780^{\text {ns }}$ & $-17.1502^{*}-$ & $-10.126^{\star *}$ & & $-32.407^{\star *}$ & $-45.893^{\star \star}$ & $-0.78991^{\star *}$ & $-1.3490^{\star}$ & $-0.186417^{\star}$ & $6.13767^{\star *}$ \\
\hline$-10 \times \mathrm{T} 3$ & $17.65^{\star \star}$ & * $54.512^{* *}$ & $15.1722^{*}$ & $20.650^{* *}$ & $27.0502^{\star *}$ & $-10.927^{\star \star}$ & $-3.0927^{\star *}$ & $10.5825^{\star}$ & $35.171^{\star \star}$ & $0.09975^{\mathrm{ns}}$ & $-0.482^{\text {ns }}$ & $0.65725^{\star \star}$ & $-4.91233^{* *}$ \\
\hline $10 \times \mathrm{T} 4$ & $-0.53^{\text {ns }}$ & $-20.080^{\star}$ & $7.4412^{\mathrm{ns}}$ & $-7.190^{\mathrm{ns}}$ & $23.5502^{\star \star}$ & $23.2245^{\star \star}$ & $5.0892^{\star \star}$ & $-5.5475^{\star}$ & $-35.771^{\star \star}$ & $0.29108^{\star \star}$ & & $0.016583^{\mathrm{ns}}$ & $-0.61267^{\text {ns }}$ \\
\hline & & & & & & & & & & & & & \\
\hline SE (Sij-Sjl) & j) 4.822 & 9.64 & 6.92 & 6.89 & 6.98 & 1.460 & 1.002 & 4.25 & 10.47 & 0.099729 & 0.58576 & 0.080946 & 0.5879 \\
\hline
\end{tabular}

For abbrevitaions, see Table 4.

\section{DISCUSSION}

GY is determined by a highly complex process; therefore, a better understanding of the factors that improve yield will benefit the selection of parents for crosses. In a dry environment, direct selection for yield is not sufficient because of the variable environment and genotype $x$ environment interaction (Richards et al., 2002).

The results in the present study were consistent with those of Kirda et al. (2005) as the maize GY under normal irrigation was significantly higher than under water deficit conditions $(50 \%$ of normal irrigation). In maize, a decrease in water availability is associated with a loss of grain weight (Edmeades et al., 1992). Our results are very much in accordance with this conclusion, as we found that yield was very much dependent on the movement of water into the plant body along 
with nutrients in dissolved form. Yield under water stress conditions is actually a function of water transpiration and the harvest index (Passioura, 1977).

Our analysis indicated that genotypes associated with larger stomata were more susceptible to water stress compared to those with smaller stomata. Hinckley (1973) likewise noted that species with larger stomata are more prone to drought stress than those with smaller stomata. SF is directly related to the rate of moisture loss from the leaf surface; Wanger et al. (1996) reported that environmental factors may have a minor effect on SF. Severe moisture stress reduces survival rate (Liptay et al., 1998).

By reducing LA, water loss can be reduced during a water stress period (Bittman and Simpson, 1989). Stress conditions modify the behavior of plants and induce formation of leaves with a reduced area (Sinclair and Muchow, 2001). Similar results were reported by Liptay et al. (1998). Under normal conditions, the availability of sufficient water increases leaf area development, and enhances crop growth rate, biomass production, and GY (Regan et al., 1997).

\section{Genetic basis of drought tolerance}

One of the objectives of this study was to screen and select parents in order to improve evaluation of the hybrid progeny. General and specific combining ability effects offer advantageous genetic information for parental selection in terms of the performance of their progeny (Dhillon, 1975). GCA is the average performance of a line in hybrid combinations, while SCA is used to designate deviations of certain crosses from expectation based on the average performance of the lines involved (Sprague and Tatum, 1942).

In the present study, we found variations in the magnitude and direction of GCA effects in lines and testers. Among inbred lines, $L_{5}$ had the highest positive and significant $G C A$ effects for GYP, SC, and OC, while $\mathrm{L}_{7}$ had highly significant and negative GCA effects for $\mathrm{PH}$, LA, and SS, but highly significant and positive GCA effects for SC. Line $L_{2}$ had the highest positive and significant GCA effects for NKE, GYP, NC, and PC under normal irrigation conditions.

Under water stress, line $\mathrm{L}_{8}$ had the highest negative and significant GCA effects for $\mathrm{PH}$, LA, and SF but highest positive and significant GCA affects for NKE, SC, and OC. Line $L_{7}$ had the highest negative and significant GCA effect for $\mathrm{PH}$ and LA, and also the highest positive and significant GCA effects for NC, PC, and SC. Line $L_{9}$ had the highest negative and significant GCA effects for $\mathrm{PH}$, and the highest and positive and significant GCA effects for NKE, NC, and PC. $\mathrm{L}_{7}$ had the highest negative and significant GCA effects for $\mathrm{PH}$ and LA, and the highest positive and significant GCA for SC under both normal and water stress conditions. Line $L_{3}$ had the highest positive and significant GCA effects for NKE and GYP. $L_{1}$ possessed the highest positive GCA effects for TGW and OC. $L_{10}$ had the highest negative and significant GCA effect for SS under both normal and water stress conditions.

Among crosses, $\mathrm{L}_{3} \times \mathrm{T}_{4}$, had the highest negative and significant SCA effects for $\mathrm{PH}$ and $\mathrm{LA}$, and the highest positive and significant GCA effects for the parameters NKE and SC. The new genetic combination $\mathrm{L}_{9} \times \mathrm{T}_{4}$ had the highest positive and significant SCA effects for the characters TGW, GYP, NC, and PC under normal irrigation conditions.

Among crosses, $L_{9} \times T_{1}$ had the highest negative and significant SCA effects for $\mathrm{PH}$ and $L A$, and had highest and significant effects for SC. The cross $L_{3} \times T_{4}$ had the highest and significant effects for GYP and SC.

$\mathrm{L}_{6} \times \mathrm{T}_{3}$ was the best cross combination for $\mathrm{SS}$ under both normal and water stress conditions, 
while the crosses $L_{7} \times T_{2}$ and $L_{3} \times T_{4}$ were the best crosses for NKE and SC under both conditions.

\section{CONCLUSIONS}

The best hybrid combinations are not always due to parents with best general combining ability; both hybrid means and the GCA of parents therefore should be considered together. We identified hybrids with high mean SCA effects along with parents with high GCA effect as a consequence of a high concentration of favorable alleles. Such genotypes will be of value for breeders. Therefore, we conclude that: LA, LRL, SS, SF, and SR are good selection criteria for drought tolerance with high heritability values. Among the germplasms tested, accessions 014955, 015084, 015114, Sahiwal-2002, Agaiti-2002, Ev-5098, and Ev-6098 are drought tolerant, whereas accessions 015167, 015224, 015135, 015030, 015125, 015262, and 015129 are drought susceptible. From the results of the GCA analysis, lines $L_{1}, L_{3}, L_{7}$ and $L_{10}$ could be discriminated as favorable, while the tester $\mathrm{T}_{4}$ could potentially be used in a hybridization program. The crosses $\mathrm{L}_{3} \times \mathrm{T}_{4}, \mathrm{~L}_{9} \times \mathrm{T}_{4}, \mathrm{~L}_{3} \times \mathrm{T}_{4}$, and $\mathrm{L}_{9} \times \mathrm{T}_{1}$ had outstanding performance values and were the best cross combinations for both normal and water stress field conditions.

\section{Conflicts of interests}

The authors declare no conflict of interest.

\section{ACKNOWLEDGMENTS}

Research supported by the Pakistan Agricultural Research Council, Islamabad, Pakistan. I also thank the National Agricultural Research Centre, Islamabad, Pakistan and Maize and Millet Research Institute, Sahiwal, Pakistan for providing the different germplasms needed to initiate the experiment. I also acknowledge the technical assistance and moral support of all Scientists and staff of PARC Research and Training Station, Multan, Department of Plant Breeding and Genetics, Faculty of Agricultural Sciences, Bahauddin Zakaryia University, Multan, Pakistan and Arid Zone Research Institute PARC, Bahawalpur, which enabled the successful completion of the study.

\section{REFERENCES}

Allard RM (1960). Principles of Plant Breeding. John Wiley and Sons, Inc., New York.

Aly RSH and Hassan MMM (2011). Combining ability of grain yield and yield components in maize. Egypt. J. Plant Breed. 15: 149-161.

Anonymous (2009-2010). World Wheat, Corn and Rice production. Economics, Statistics, and Market Information System, United States Department of Agriculture.

Anonymous (2012-2013). Pakistan Economic Survey. Federal Bureau of Statistics, Ministry of Food Security, Islamabad.

Ashish S and Singh IS (2002). Evaluation and classification of exotic inbreds over locations based on line $\mathrm{x}$ tester analysis in maize (Zea mays L.). Crop Improv. 29: 184-189.

Barata C and Carena MJ (2006). Classification of North Dakota maize inbred lines into heterotic groups based on molecular and testcross data. Euphytica 151: 339-349.

Bittman S and Simpson GM (1989). Drought effect on leaf conductance and leaf rolling in forage grasses. Crop Sci. 29: 338344.

Chaudhary RR and Joshi BK (2005). Correlation and path coefficient analysis in sugarcane. Nepal Agric. Res. J. 6: 24-27.

Ceyhan E (2003). Determination of some agricultural characters and their heredity through line $x$ tester method in pea parents and crosses. Selcuk University, Graduate School of Natural and Applied Sciences, Istanboul. 
Dhillon BZ (1975). The application of partial diallel crosses in plant breeding. A review. Crop Improv. 2: 1-7.

Edmeades GO, Bolanos J and Laffitle HR (1992). Progress in breeding for drought tolerance in maize. P. 93-III. In: Proc. 47th Annu Corn and Sorghum Ind. Res. Conf. (Wilkinson D, ed.). ASTTA, Washington.

Fan XM, Tan J, Yang JY, Liu F, et al. (2002). Study on combining ability for yield and genetic relationship between exotic tropical, subtropical maize inbreds and domestic temperate maize inbreds. Sci. Agric. Sin. 35: 743-749.

Fan XM, Chen HM, Tan J, Xu CX, et al. (2008). Combining abilities for yield and yield components in maize. Maydica 53: 39-46.

Fehr WR (1993). Principles of cultivar development. MacMillan Publication Co., New York.

Hallauer AR and Miranda JB (1990). Quantitative genetics in maize breeding. 2nd edn. lowa State Univ. Press, Ames.

Hinckley TM (1973). Responses of black locust and tomato plants after water stress. Hort. Sci. 8: 405-407.

Kara SM (2001). Evaluation of yield and yield components in inbred maize lines. I. Heterosis and line $\mathrm{x}$ tester analysis of combining ability. Turk. J. Agric. For. 25: 383-391.

Kauffman KD, Crum CW and Lindsey MF (1982). Exotic germplasms in a corn breeding program. Illinois Corn Breeders School 18: 6-39.

Kempthorne O (1957). An introduction to genetic statistics. John Wiley and Sons Inc., New York.

Khan MD, Khali IH, Khan MA and Ikramullah (2004). Genetic divergence and association for yield and related traits in mash bean. Sarhad J. Agric. 20: 555-561.

Khodadadi M, Fotokian MH and Miransari M (2011). Genetic diversity of wheat (Triticum aestivum L.) genotypes based on cluster and principal component analyses for breeding strategies. Aust. J. Crop Sci. 5: 17-24.

Kirda CS, Topcu H, Kaman AC, Ulger A, et al. (2005). Grain yield response and N-fertiliser recovery of maize under deficit irrigation. Field Crops Res. 93: 132-141.

Liptay A, Sikkema P and Fonteno W (1998). Transplant growth control through water deficit stress: a review. Hort. Technol. 8: $540-543$.

Morris ML, Rispoulos J and Beck D (1999). Genetic changes in farmer-recycled maize seed: a review of the evidence, CIMMYT Economics Working Paper No. 99-07, CIMMYT, Mexico.

Motawei AA (2006). Additive and non-additive genetic variances of important quantitative traits in new maize inbred lines via line $x$ tester analysis. J. Agric. Sci. Mansoura Univ. 31: 6855-6865.

Mousa SThM and Aly RSH (2011). Combining ability for grain yield and some related traits of newly yellow maize (Zea mays L.) inbred lines. J. Agric. Chem. Biotechnol. Mansoura Univ. 2: 331-341.

Panhwar RH, Keerio HK, Khan MA, Rajpoot MA, et al. (2003). Relationship between yield and yield contributing traits in sugarcane (Saccharum officinarum L.). Pak. J. Appl. Sci. 3: 97-99.

Passioura JB (1977). Grain yield, harvest index, and water use of wheat. J. Aust. Inst. Agric. Res. Sci. 43: 117-120.

Regan KL, Siddique KHM, Tennant D and Abrecht DG. (1997). Grain yield and water use efficiency of early maturing wheat in low rainfall Mediterranean environments. Aust. J. Agric. Res. 48: 595-603.

Richards RA, Rebetzke GJ, Condon AG and Van Herwaaden AF. (2002). Breeding opportunities for increasing the efficiency of water use and crop yield in temperate cereals. Crop Sci. 42: 111-121.

Sinclair TR and Muchow RC (2001). System analysis of plant traits to increase grain yield on limited water supplies. Agron. J. 93: 263-270.

Singh RK and Chaudhary BD (1985). Biometrical methods in quantitative genetics analysis. Kalyani Publishers, New Delhi, 38-54.

Sprague GS and Tatum IA (1942). General vs specific combining ability in single crosses of corn. Agron. J. 34: 923-932.

Wanger F, Below R, Klerk PD, Dilcher DI, et al. (1996). A natural experiment on plant acclimation: lifetime stomatal frequency response of an individual tree to annual atmospheric $\mathrm{CO}_{2}$ increase. Proc. Natl. Assoc. Sci. U. S. A. 93: 11705-11708. 